\title{
Changes in the fish fauna and fisheries in the Slovak section of the Danube River: a review
}

\author{
J. Holcík
}

Institute of Zoology, Slovak Academy of Sciences, Dúbravská cesta 9, 84506 Bratislava, Slovak Republic. E-mail: juraj.holcik@ savba.sk

The fish diversity of the Slovak segment of the Danube (representing the transitional zone from the rhithron to the potamon) was under the control of the inland delta which existed in this region until 1992. Seventy-six species were recorded in the studied river section: 61 species were native, 11 were exotic, 5 or 7 were invaders from the lower sections of the Danube, 3 species (and one form) became extinct, and 7 species were not detected during the past 20 years. The increasing pollution until 1985 decreased the fish species richness, but the improvement of water quality thereafter rose their number. However, the construction of the Gabcíkovo River Barrage System put in operation in October 1992 started to change substantially fish species richness and quantity, and fish catch. The formerly functional inland delta controlled by the pulsating discharge disappeared, and was changed to an artificial system of isolated or only marginally connected habitats. The upstream fish migration was stopped by the Gabcíkovo dam and weirs in Cunovo. Therefore, the fish fauna of the side arms lost contact with fish of the main channel and of the bypass canal downstream. The loss of spawning habitats had fatal effects, especially for the wild carp and the pike, which number rapidly decreased. In general, the number of fish species, their density, and fish catch decreased significantly. To improve the situation, it is proposed: 1) to restore the bilateral connection between the main channel and the side arms, 2) to ensure fish migration between the main channel and the side arms, and 3) to simulate the original flooding of the floodplain.

Keywords: Danube River, fish diversity, fisheries, dams, hydraulic engineering impact.

\section{Introduction}

The following review describes the fish community and the fisheries of the Slovak part of the Danube River (i.e., the Slovak-Austrian, Slovak, and SlovakHungarian stretches), and their changes over more than 100 years. The data were taken from previous works (Marsilius 1726, Grossinger 1794, Heckel \& Kner 1858, Kornhuber 1863, Herman 1887, Ortvay 1902), and from thorough ichthyological studies carried out from 1953 to 1989 (Balon 1966, 1967a, b, Holcík et al. 1981, Bastl et al.1990) with addition of recent information (Holcík 1996a, 1998b, c, Holcík et al. 1992, 2001, Stráňai 1997, Stráňai \& Andreji 2001, Ahnelt et al. 1998, Kautman 2000, 2001). The data collected after 1992 were only used exceptionally, because of differences in methodologies (Cerný 1995, 1999) and/or controversial statements (Cerný \& Kvas- zová 1999). Finally, I did not accept at all information concerning the Cunovo reservoir (Kirka 1997, 1998, 1999) because they lack concrete and reliable data. The results of the ichthyological investigations were more complete up to October 1992. Although there was some continuation in ichthyological research afterward, their amount and quality were incomparably low (the worsened economical situation after 1989 strongly limited scientific activity). Before October 1992, the man-made impact on the Danube was relatively minor, and allowed the maintain of more or less natural environmental conditions. In October 1992, the damming of the Danube at Cunovo and the construction of the Gabcíkovo River Barrage system (GRBS) dramatically changed the environmental conditions for fish. Apart from the species richness or the alpha di versity, i.e., the number of species, I shall also touch the problem of the heterogeneity, which is the second 
important character of the species diversity problem (Krebs 1985). The scientific nomenclature was mostly used according to Kottelat (1997). To properly understand the situation in this segment of the Danube, the environmental conditions are detailed hereafter.

\section{Characteristics of the Slovak segment of the Danube}

The following characteristics of the Slovak segment of the Danube were compiled from the papers by $\mathrm{Mu}$ cha \& Dub (1966), Holcík et al. (1981), Makovinská (1999) and literature herein.

\section{Physiography}

The entire Slovak segment of the Danube River amounts to $172 \mathrm{~km}$. It enters the territory of Slovakia at its confluence with the Morava River (river kilometre 1880.2) at an elevation of $133 \mathrm{~m}$ a.s.l., and leaves Slovakia at the confluence with the Ipel (Ipoly) River (r.km 1709.2) at an elevation of $101 \mathrm{~m}$ a.s.l. (Fig.1). The upper Devín-Wolfsthal section totalling $7.5 \mathrm{~km}$ makes up the Slovak-Austrian frontier. Both banks of the Bratislava (Karlova Ves) - Rajka section (which is $23.7 \mathrm{~km}$ long) belong to Slovakia and the following $140.8 \mathrm{~km}$ section between Rajka and the mouth of Ipel River forms the Slovak-Hungarian frontier. The width of the Danube is $200-300 \mathrm{~m}$ at Bratislava and increases to 400-700 m before leaving the territory of Slovakia. This part of the Danube is noteworthy for its gradient conditions. The Danube gradient changes in the vicinity of the village Sap (formerly Palkovicovo; r.km 1810). Upstream from Sap, the Danube gradient is $0.31 \%$, while downstream the gradient decreases to $0.10 \%$. The mean overall gradient of the Slovak Danube is about $0.19 \%$ o. Differences in the gradient are also reflected by the values of current $\mathrm{v}$ e 1 o c i t y. Over the gradient break, the maximum current velocity ranged from 2.0 to $3.5 \mathrm{~m} . \mathrm{s}^{-1}$, and beneath it the current velocity decreased to $0.7-1.8 \mathrm{~m} . \mathrm{s}^{-1}$. Thus, the section upstream of Bratislava (r.km 1870) is an erosional zone; the section downstream of Bratislava is an intermediate zone, whereas the depositional zone starts downstream of the village Sap. The high current velocity is responsible for the Danube's considerable transporting capacity. Within the Bratislava profile, the Danube annually transports about $630000 \mathrm{~m}^{3}$ of pebble and gravel, and about 7 million tons of suspended solids.

The Alpine character of the Danube is manifested both in its discharge and temperature regimes. The water level fluctuation depends upon the thawing of the
Alpine glaciers. The rhythmical fluctuation of the water level (or the flood-pulse effect, Junk et al. 1989) is characteristic in this segment of the Danube, resulting in the flooding of the floodplain twice a year. According to long-term observations, the first spring flood starts at the beginning of February to culminate by the mid of March, and fades away in April. The second or summer flood starts in May, culminates in July and ends at the beginning of September. The mean discharge amounts to $2050 \mathrm{~m}^{3} . \mathrm{s}^{-1}$, water starts to enter the floodplain at $3500-4000 \mathrm{~m}^{3} \cdot \mathrm{s}^{-1}$, and the complete flooding begins at $4500 \mathrm{~m}^{3} \cdot \mathrm{s}^{-1}$. Due to its Alpine cha$r$ a c t e r, the Danube in this area has a relatively low temperature. The average annual water temperature of the Danube at Bratislava is $9.6{ }^{\circ} \mathrm{C}$. The average longterm maximum water temperature is $17.4{ }^{\circ} \mathrm{C}$ in June and $17.5^{\circ} \mathrm{C}$ in August.

From the limnological point of view, the overall Slovak stretch of the river may be characterised as the beginning of the foothill zone (hyporhitron-metapotamon). Owing to the gradient change and the lowering of the transporting capacity of the Danube, a vast floodplain with numerous side arms, swamps and lakes - the inland delta - was created in the past. How e ve r, the intensive regulation adjustments which aimed at improving navigation considerably diminished its size. Before 1992, the area of the floodplain delimited by the large river dike at both banks was about 22685 ha. Of this, about 3114 ha consisted in the arm system communicating with the Danube.

\section{Water quality}

Long-term observations revealed that the water quality of this segment of the Danube considerably changed during past decades. According to a complex analysis of sanitary, economic and limnological conditions, the River Danube entering the Slovak territory was heavily polluted in the beginning of 1970 as a consequence of both industrialisation (especially construction of chemical and petrochemical industries) and increasing number of inhabitants in vast urban centres on both banks of the Danube. The quality of the water was formerly classified as being of the $3^{\text {rd }}$ degree of purity (beta-mesosaprobia), and deteriorated to the $4^{\text {th }}$ degree of purity (alpha-mesosaprobia). The self-cleaning capability of the Danube decreased considerably and the toxic effects of industrial wastewaters exceeded the bearable limits for human health and for the life of some organisms. The most dangerous were the wastewaters from petrochemical works that contained a considerable and increasing amount of oil. Although the fish kills were only rarely observed 
(3)

FISH FAUNA AND FISHERIES OF THE DANUBE RIVER

179
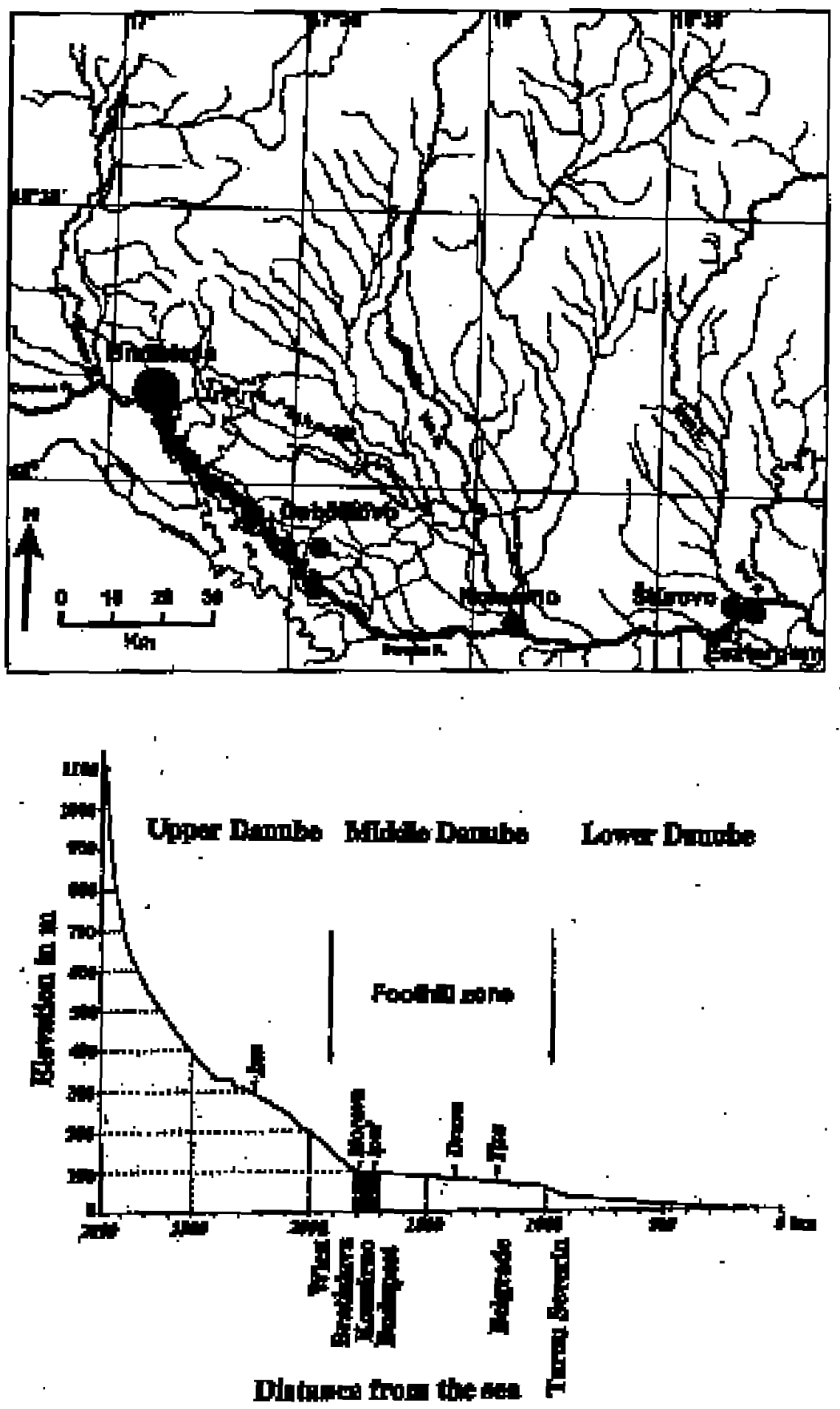

Fig. 1. Slovak segment of the Danube River (top), and profile of the Danube from its source to the Black Sea (bottom). Hatched bar indicates the Slovak segment. 
(e.g., in summer 1973), the fish fauna was significantly affected. Some sensitive fish species, such as the brown bullhead Cottus gobio Linnaeus, 1758, the minnow Phoxinus phoxinus (Linnaeus, 1758), the spirlin Alburnoides bipunctatus (Bloch, 1782) and the sterlet Acipenser ruthenus Linnaeus, 1758, disappeared from the main channel of the Danube below Bratislava. Other species, like the barbel Barbus barbus (Linnaeus, 1758) occurred only rarely. The construction of water purification stations in Vienna, Schwechat and Bratislava at the beginning of the 1980s considerably improved the water quality, and some fish species which disappeared from some river segments below Bratislava re-established their occurrence and populations. There was a considerable increase in eutrophication owing to the increasing amount of nutrients coming from the watershed. The present mean concentrations of nitrogen salts are 3 times higher than 40 years ago. On the other hand, the amount of phosphorus, which increased during past 30 years, started to decrease since the middle of the eighties. The rise of nutrients was accompanied by an increase of $\mathrm{pH}$ values. During the past 8 years, the mean $\mathrm{pH}$ increased from 7.7-7.8 to 8.1. In sum it may be stated that the increase of the Danube River pollution which characterized the 19551985 period has been stopped, and since that time an improvement in water quality has been observed.

\section{Modification of the Danube flow since 1960.}

Large changes in the water level have been observed during the last two decades. Since 1960, the water level profile for a discharge of $1000 \mathrm{~m}^{3}$ has decreased by 1 to $2 \mathrm{~m}$ between r.km 1870 and 1840, and between r.km 1805 and 1785. Two factors were responsible for the river bed degradation: 1) the effect of 49 dams built in the German and especially in the Austrian stretches of the Danube lowered the amount of sediments to about $1 / 4$ of the formerly transported volume, and 2) the large scale dredging along the Danube river from both the Slovak and Hungarian sides. The volume of dredged material at some river segments was up to 1.52.0 million $\mathrm{m}^{3}$.year ${ }^{-1}$. The largest amount was dredged out in the city of Bratislava (r.km 1860-1870), where in some years up to 2.5 million $\mathrm{m}^{3}$.year-1 have been excavated. This dredging considerably affected the timing and volume of water entering the side arms and the floodplain. Part of the inland delta between r. $\mathrm{k} \mathrm{m}$ 1860 and 1840 was flooded and their arms filled with water later than before, and with lower amounts of wa$\mathrm{t}$ e r. In some years and seasons, some of these arms completely dried up and this part of the floodplain was not flooded. However, most of the floodplain was still under the rhythmical pulses of the floods, the ecosys- tem of the inland delta did not show substantial deviations, and the characteristic responses of fish stocks and catches to changes in the hydrological regime remained as expected.

The most serious impact upon the abiotic and biotic conditions of this segment of the Danube was the construction of the Gabcíkovo River Barrage System (GRBS) between 1978 and 1992. After the damming of the Danube at Cunovo (r.km 1852) in October 1992, most of the water from the storage reservoir (with an area of about 4000 hectares) was brought down to the concrete diversion canal. This canal runs along the left-hand side of the river dike, above ground level. The canal is divided by the Gabcíkovo hydroelectric power plant into the upstream (headwater) and downstream (tailwater) sections. The difference in the water level between the headwater and tailwater section varies from 16 to $23 \mathrm{~m}$. The slopes running all along the length of this canal are made from concrete and the bottom is strengthened by compacting the existing clay loam followed by a layer of gravel. The original riverbed of the Danube is now supplied by a limited volume of water amounting to $250-600 \mathrm{~m}^{3} \cdot \mathrm{s}^{-1}$. Thus, the water level of the old Danube is 3-5 m below the ground level of the former floodplain and the contact between the side arms and the Danube is completely interrupted. The remaining left hand arms are supplied by the intake structure taking water from the bypass canal at Dobrohost' (r.km 1840) with a discharge capacity of up to $240 \mathrm{~m}^{3} \cdot \mathrm{s}^{-1}$. To keep the water in the arms, these were converted to a system of cascades formed by 11 weirs between r.km 1840 and 1820 . One fish way was also built between the old riverbed and the lower part of the anabranch system at r.km 1821. However, the flow from the weir openings is over $1 \mathrm{~m} . \mathrm{s}^{-1}$ and the fish way is not properly constructed, so the upstream fish migration from the Danube is not possible, as shown by the tagging of fish downstream of Gabcíkovo and Cunovo. Natural and pulsating flooding of the inland delta was terminated. Although the artificial flooding of the former floodplain was planned, it was realised only in 1995, 1997 and 2000. However, these floods did not simulate the natural floods as their amount, timing and duration were different. The first artificial flood realised in 1995 began on 25 July, lasted until 25 August and culminated from 1 to 9 August. Because the discharge rose from 35 to only 60-131 $\mathrm{m}^{3} . \mathrm{s}^{-1}$, only a small part of the floodplain was flooded. In 1997 the artificial flooding begun on 21 April, culminating between 27-30 April (culmination lasted only 99 hours) and ended on 15 May, with similar values of discharge allowed to enter the floodplain. Relative- 
ly little information is available on the flood of 2000: it lasted from 18 June until 6 July, and the water level in the arms increased by $80-100 \mathrm{~cm}$, but the former floodplain was not flooded at all. It may be seen that in 1995 the floods were too late and in 1997 too short, and in both years the area covered by water was too small for the successful spawning of phytophil and phytolithophil fishes. It is also necessary to mention that in the arms fed by the water from the bypass canal, the abundance and biomass of zooplankton decreased substantially and was far below the values found in the predammed conditions (Vr a n o v s ký 1995, 1997, Vr anovský \& Illyová 1999). A similar observation was made for the macrozoobenthos biomass (Krno et al. 1999).

After the construction of the GRBS and its operational introduction in October 1992, the formerly functional ecosystem of the inland delta became extinct. It was replaced by an artificial system of more or less isolated habitats. The dramatic alterations of both the hydrological regime and the habitat diversity induced subsequent decrease of the fish food base and the loss of spawning, feeding and wintering grounds for fishes. Con s e que n t ly, the mean annual fish catch, calculated for the period after the damming of the river, dropped by $87 \%$ in comparison with the 1961-1972 period when the construction of the GRBS has been planned (Holcík 1998a, Balon \& Holcík 1999).

\section{Fish species richness (alpha diversity)}

Although this segment of the Danube is relatively short in comparison with the longest Slovak rivers Váh $(403 \mathrm{~km})$, Hron $(298 \mathrm{~km})$, Hornád $(286 \mathrm{~km})$, and Ipel $(232 \mathrm{~km})$, it houses the richest fish fauna. Table 1 shows that 75 fish species were recorded, and another one is anticipated to occur in this stretch of the Danube River. The native species amount to $61(80.3 \%)$, introduced exotic species to $11(14.5 \%)$, and recent invaders to $5(6,6 \%)$ or $6(7.9 \%)$, if it is supposed that one new invading species is anticipated. Three (3.9\%) species and one form (diadromous form of Acipenser gueldenstadtii) became extinct, the presence of other 7 species $(9.2 \%)$ was not recorded during past 20 years. The richness of this segment of the Danube can be explained by two reasons: 1) this stretch of the river represents the beginning of the foothill zone (Fig.1), or, more precisely, the transitional zone between the foo thill and the lowland zones (i.e., the hyporhitron-epi potamon and metapotamon, or the intermediate zone according to the classification of Illies \& Botosaneanu (1963) and Cummins (1972) respectively), and 2) the gradient change of the Danube, causing the develop- ment of a quite complicated braided belt and a vast inland delta with a complex network of numerous side arms. Thus, miscellaneous fish species differing in their environmental requirements may occur together in this relatively short river segment. Various types of environment including the eupotamon, parapotamon, plesiopotamon and paleopotamon (Roux 1982, Holcík et al. 1989) and the countless number of ecotones have created the diverse combination of environmental conditions suitable for the assembly of different fish species.

\section{Species diversity and equitability}

It was found that species diversity and equitability in two types of floodplain side arms were diff e $r$ e $n t$ (Holcík 1998a). Table 2 shows clear differences in several parameters between the main channel (eupota mon) and two types of floodplain side arms (parapota mon and plesiopotamon). Table 2 also indicates increasing values of parameters from the eupotamon towards the floodplain margin. This suggests that in the main channel of large rivers with inland delta, the indexes of species diversity and equitability are higher than those in the side arms (the actual values for all indexes, especially the species richness in the main channel, are certainly much higher because of a difference in fishing gear used to obtain the data; the values for the main channel represent catches by commercial hauls using a 40x40 mm mesh size net, while those for the parapotamon and pleisopotamon arose from catches obtained by small mesh size hauls $(10 \times 10 \mathrm{~mm})$ combined with trap nets, gill nets and electroshockers). In this respect the Little Danube data are not considered, as this water body is a highly modified flowing arm of the Danube. High species richness and other ecological indexes of the eupotamon are just due to the inland delta existence, which represents one of the ecotone forms (Schiemer et al. 1995). Moreover, the inland delta also supplies the main channel with species reproducing there (e.g., phytophils) which find conditions for their propagation in the main channel. It is necessary to point out that the biological productivity of the inland delta of the floodplain rivers is generally the highest. In this stretch of the Danube, the total fish production is well over $1000 \mathrm{~kg} \cdot \mathrm{ha}^{-1}$ in average, or over 200 kilograms of the available production per hectare (Holcík, 1996a).

Papers dealing with the problem of heterogeneity of fishes are rather rare (e.g. Talbot et al. 1978, Sale \& Williams 1982, Jepsen 1997). As explained elsewhere (Holcík 1998a), this index, and also the species richness and equitability, depend on the water level and 
Table 1. List of the fish species occurring in the Slovak segment of the Danube river. $1=$ status, $2=$ reproductive guild $3=$ preferred habitat, $4=$ conservation status (IUCN classification, see text). Symbols: $\bullet=$ present,,$=$ not recorded during the past 20 years, $\mathrm{x}=$ extinct, ? = occurrence anticipated, $(?)=$ identity not properly known; $*=$ introduced exotic species, $* *=$ recent invader; $\mathrm{R}=$ rheophil, $\mathrm{L}=$ limnophil, $\mathrm{E}$ - eurytopic; $\mathrm{A}=$ nonguarders: $\mathrm{A} .1=$ open substratum spawners; A.1.1 = pelagophils, A.1.2 = lithopelagophils, A.1.3 = lithophils, A.1.4 = phytolithophils, A.1.5 = phytophils, A.1.6 = psammophils; A.2 = brood hiders; A.2.3 = lithophils, A.2.5 = ostracophils; B = guarders: B.1 $=$ substratum choosers; B.1.3 = lithophils, B.1.4 = phytophils; B. $2=$ nest spawners; B.2.2 = polyphils, B.2.4 = ariadnophils, B.2.5 = phytophils, B.2.7 = speleophils.

\begin{tabular}{|c|c|c|c|}
\hline 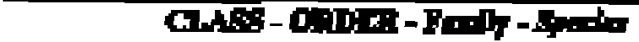 & 1 & 7 & 9 \\
\hline
\end{tabular}

\section{1. Franation}

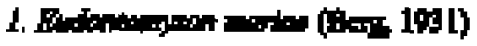

A.3 $\mathrm{I}$ CA

\section{ACTHQTHTYGII}

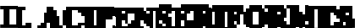

\section{2, Ariph -ith}

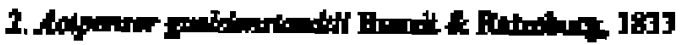

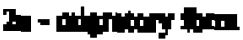

$$
\begin{aligned}
& \text { Zb-m-int fom }
\end{aligned}
$$

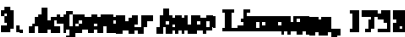

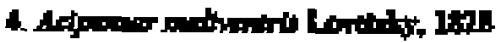

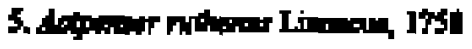

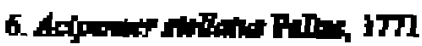

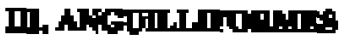

\section{An thidr}

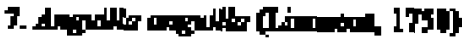

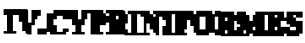

\section{Cy+ratro}

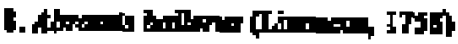

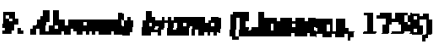

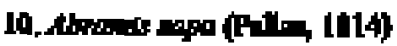

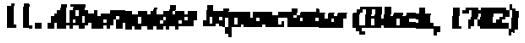

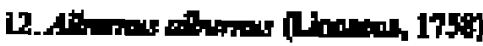

\begin{tabular}{|c|c|c|}
\hline $\mathrm{R}$ & Al] & $\mathbf{R}$ \\
\hline & A.1.2 & $\mathbf{R}$ \\
\hline $\mathbf{x}$ & Al.2 & $\mathrm{x}$ \\
\hline 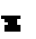 & A12 & $\mathbf{B}$ \\
\hline & A.L2 & $\mathbf{R}$ \\
\hline 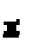 & A, L, & $\mathbf{R}$ \\
\hline
\end{tabular}

- A.1 E

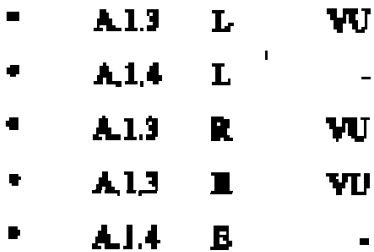


Table 1. (Continued).

\begin{tabular}{|c|c|c|c|c|}
\hline 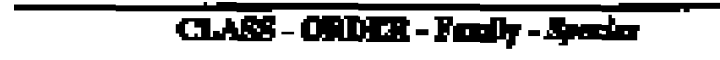 & 1 & $\mathbf{z}$ & $\mathbf{9}$ & 4 \\
\hline 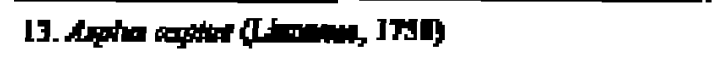 & - & A.13 & $\mathbf{R}$ & \\
\hline 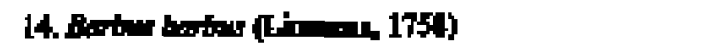 & - & A,13 & $\mathbf{E}$ & \\
\hline 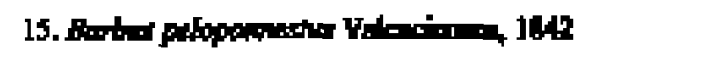 & - & A13 & $\mathbf{R}$ & DD \\
\hline 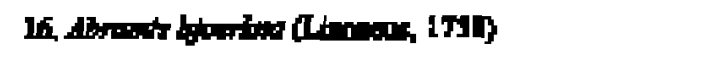 & - & Als & $\mathbf{E}$ & \\
\hline 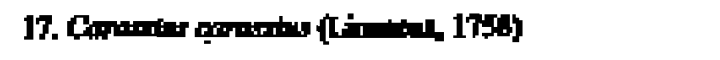 & $\cdot$ & A.1.5 & $\mathbf{L}$ & $\mathbf{x}$ \\
\hline 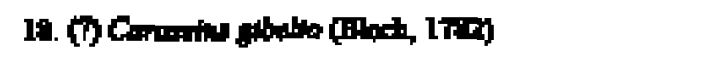 & - & A. 1.5 & $\mathbf{E}$ & \\
\hline 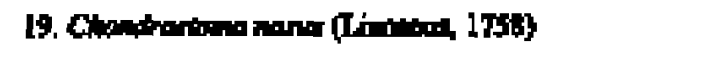 & 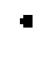 & L.1.3 & $\mathbf{x}$ & Yu \\
\hline 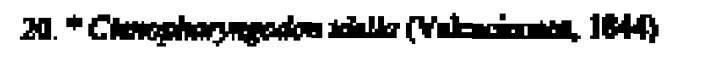 & $\bullet$ & Al.1 & $\mathbf{E}$ & \\
\hline \multicolumn{5}{|l|}{ 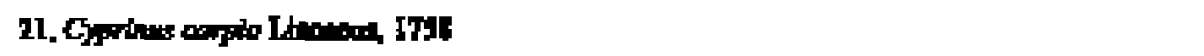 } \\
\hline 24 - 2 - & $\cdot$ & H.S & $\mathbf{R}$ & $\mathbf{W 1}$ \\
\hline 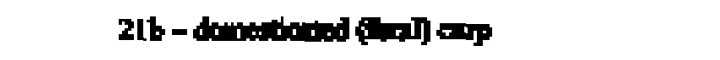 & 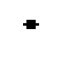 & Als & $\mathbf{L}$ & \\
\hline 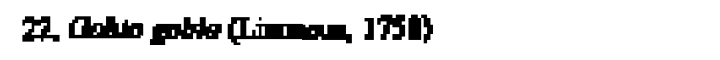 & - & AL.6 & $\mathbf{E}$ & \\
\hline 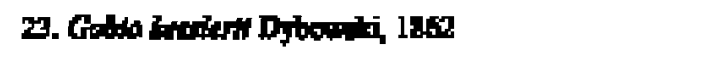 & $\bullet$ & A.L.6 & $\mathbf{R}$ & $\mathbf{c k}$ \\
\hline 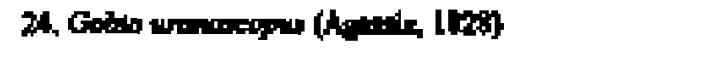 & $\bullet$ & A.6.6 & $\mathbf{R}$ & $\mathbf{C H}$ \\
\hline 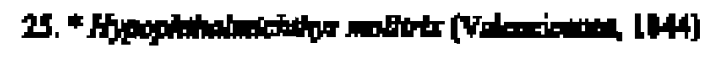 & $\bullet$ & A.1.1 & $\mathbf{R}$ & 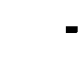 \\
\hline 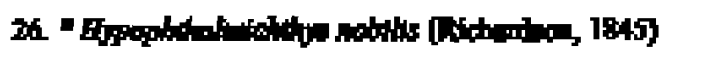 & - & A.1.1 & $\mathbf{H}$ & - \\
\hline 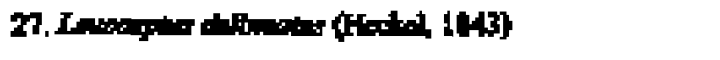 & $\bullet$ & B.I.4 & $\mathbf{L}$ & vu \\
\hline 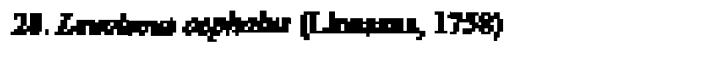 & * & Al. 3 & $\mathbf{R}$ & - \\
\hline 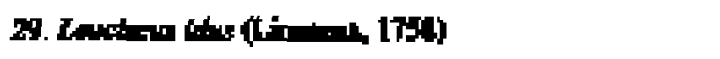 & 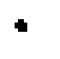 & A.t.4 & $\mathbf{E}$ & $\mathbf{v U}$ \\
\hline 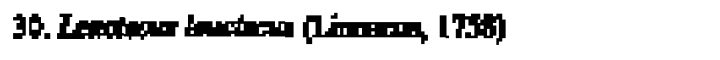 & - & A.J.3 & $\mathbf{x}$ & $\mathbf{N u}$ \\
\hline 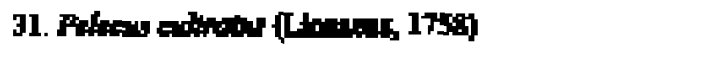 & - & A.1.1 & $\mathbf{E}$ & $\mathbf{E x}$ \\
\hline 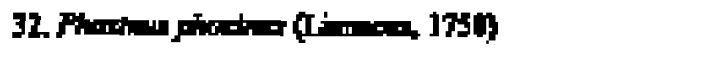 & 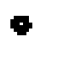 & A1.3 & $\mathbf{R}$ & $\mathbf{v u}$ \\
\hline 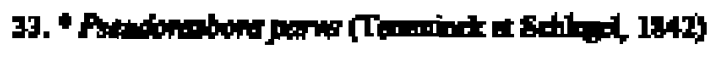 & - & B.2.2 & $\mathbf{E}$ & " \\
\hline 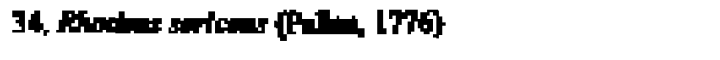 & $\bullet$ & A.s & $\mathbf{B}$ & $\mathbf{D D}$ \\
\hline 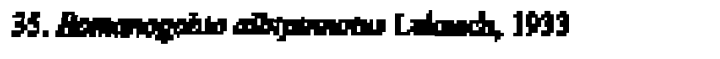 & $\bullet$ & A.1.6 & $\mathbf{E}$ & $=$ \\
\hline 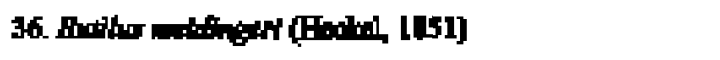 & $\bullet$ & A.1.4 & $\mathbf{H}$ & $\mathbf{m}$ \\
\hline 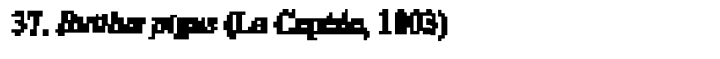 & - & A. 1.4 & $\mathbf{R}$ & $\mathbf{C R}$ \\
\hline 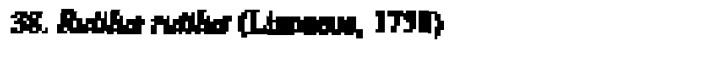 & $\cdot$ & A.1.4 & $\mathbf{E}$ & 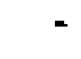 \\
\hline 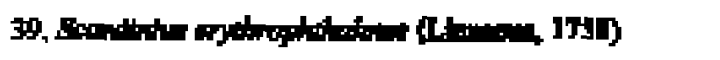 & • & ALS & $\mathbf{l}$ & $=$ \\
\hline 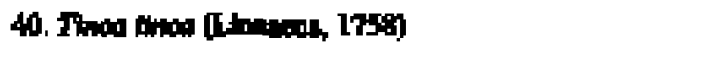 & $\cdot$ & A.js & $\mathbf{L}$ & - \\
\hline 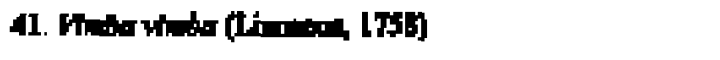 & - & A.1.3 & $\mathbf{k}$ & $\mathbf{M U}$ \\
\hline \multicolumn{5}{|l|}{10 contente } \\
\hline 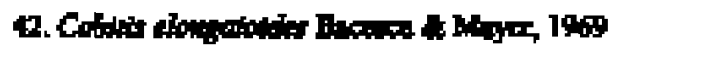 & - & A.1,1 & $\mathbf{R}$ & $\mathbf{M U}$ \\
\hline 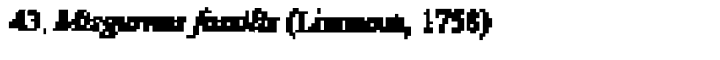 & $\bullet$ & ALs & $\mathbf{L}$ & CR \\
\hline 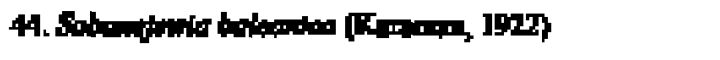 & $*$ & $\mathbf{A}, \mathbf{1}, \mathbf{I}$ & $\mathbf{R}$ & MI \\
\hline
\end{tabular}


Table 1. (Continued).

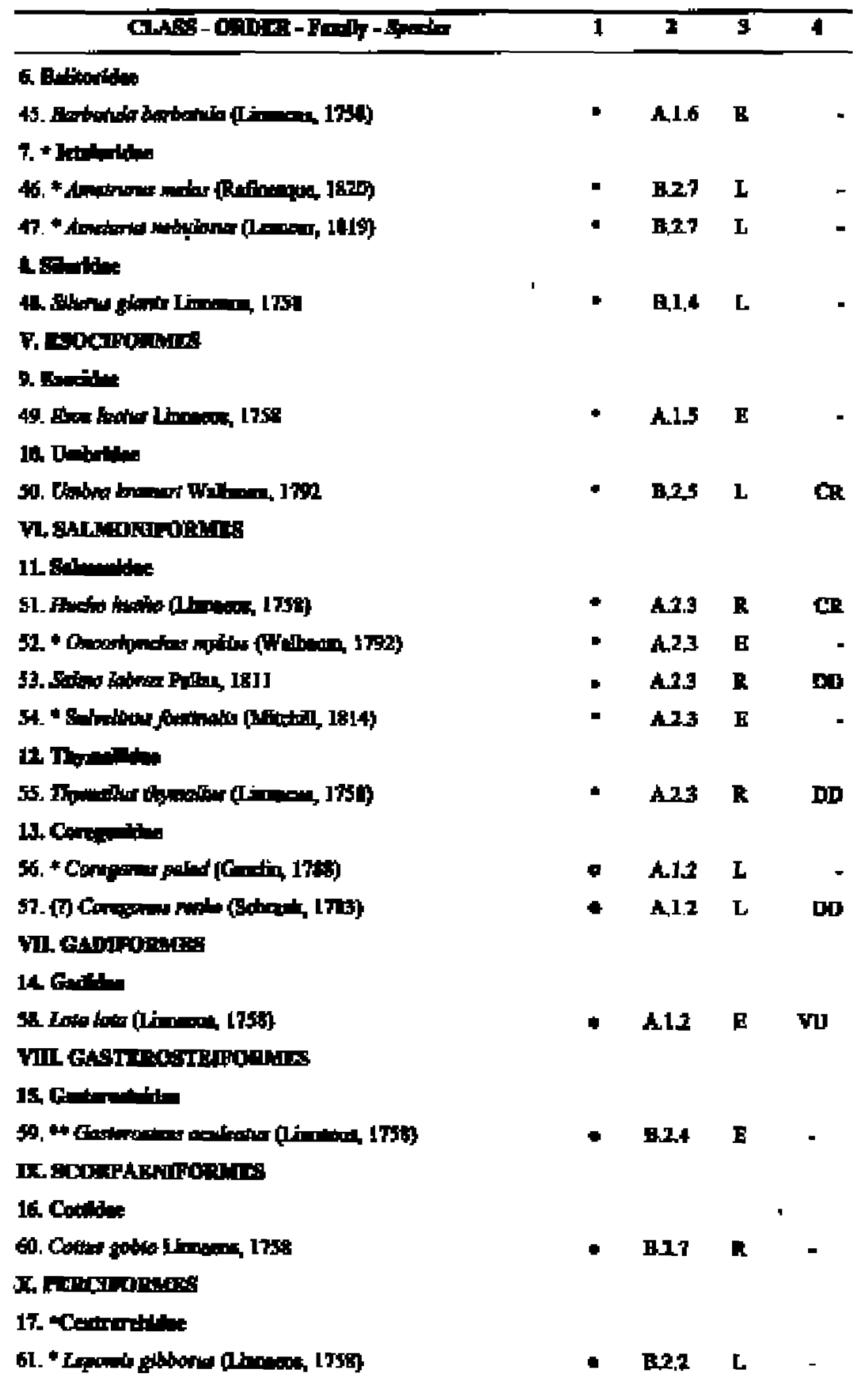


Table 1. (Continued).

\begin{tabular}{|c|c|c|c|c|}
\hline 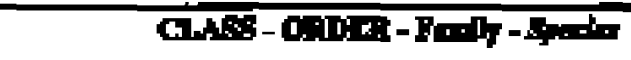 & 1 & $\mathbf{z}$ & 9 & 4 \\
\hline 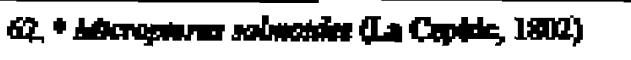 & - & B.25 & $\mathbf{E}$ & - \\
\hline \multicolumn{5}{|l|}{ Ih Fodte } \\
\hline 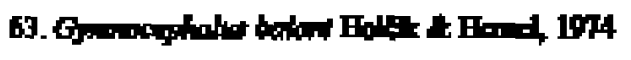 & $\bullet$ & A1.3 & $\mathbf{R}$ & YU \\
\hline 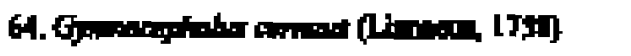 & 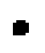 & A1.4 & $\mathbf{E}$ & - \\
\hline 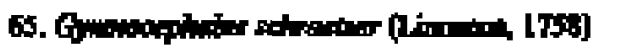 & - & H13 & $\mathbf{R}$ & YU \\
\hline 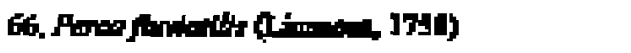 & - & A.1.4 & E & - \\
\hline 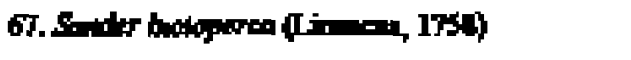 & - & B.2.5 & $\mathbf{E}$ & - \\
\hline 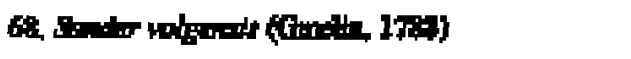 & $\bullet$ & 6.2.5 & $\mathbf{F}$ & vu \\
\hline 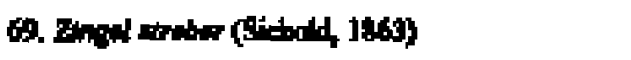 & - & A.1.3 & $\mathbf{R}$ & vu \\
\hline 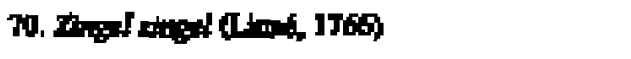 & - & As3 & $\mathbf{E}$ & cas \\
\hline 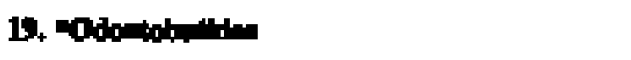 & 9 & & & \\
\hline 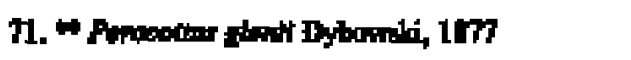 & 7 & 122 & $\mathbf{L}$ & - \\
\hline \multicolumn{5}{|l|}{24 Genting } \\
\hline 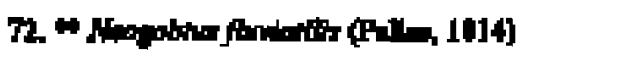 & - & E.1.3 & $\mathbf{R}$ & - \\
\hline 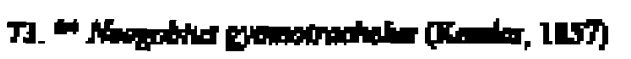 & • & H].3 & $\mathbf{E}$ & 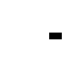 \\
\hline 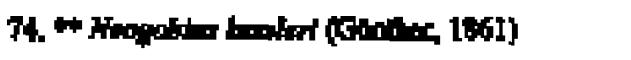 & 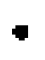 & B.13 & $\mathbf{E}$ & - \\
\hline 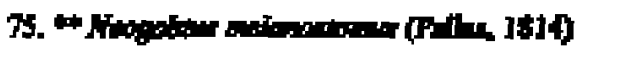 & $\boldsymbol{T}$ & B.13 & $\mathbf{E}$ & - \\
\hline 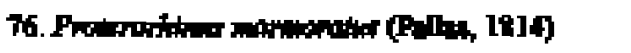 & $\bullet$ & $\mathbf{8 , 2 7}$ & $\mathbf{L}$ & - \\
\hline
\end{tabular}

season and show large fluctuations. Preliminary results revealed that the floodplain river water bodies were highly diversified and unstable systems, in which increasing species richness may, or not, increase the species diversity. However, while an increase in species richness increases ichthyomass, species diversity decreases it.

Comments on the status of some species

Petromyzontidae in this river section as well as in the entire Middle and Lower Danube are represented by the Ukrainian lamprey Eudontomyzon mariae ( B e rg, 1931) (Holcík \& Renaud 1986, Holcík 1995a, b, Holcík \& Delic 2000) and not by the Carpathian lamprey Eudontomyzon danfordi as reported earlier by Balon (1967a) and Holcík et al. (1981). Recently, it was found in the littoral of Danube between Suturovo ( r.km1820) and the mouth of the Hron River ( r.km.1817) and its identification was confirmed (Holcík et al. 2001, Holcík 2003). With regard to the habitat of ammocoetes and metamorphosed specimens, the occurrence of this species is apparently limi- ted to the old riverbed. Further information on the occurrence of the Ukrainian lamprey from this segment of the Danube, especially from the right Austrian-Hungarian shores are needed. Ukrainian lamprey may be considered as critically endangered species.

The great sturgeon or beluga, Acipenser huso Linnaeus, 1758, was represented by the winter race. It was caught in great quantities in the Danube between Komárno (r.km 1768) and Sap (r.km 1810), the locations of its main spawning grounds. It regularly migrated up to Bratislava (r.km 1870) and also entered the lower courses of large tributaries such as the Morava, Váh and Hron rivers. The major fishery was concentrated in the Little Danube near the mouth of the V.h River and the village of Kollárovo. A dramatic decline of its catches, as a consequence of overfishing, started as early as the $16^{\text {th }} \mathrm{century}$. The last specimens weighing 140 and $150 \mathrm{~kg}$ in this segment of the Danube were caught at Vojka (r.km 1837) and Stúrovo (r. k m 1719) in 1910 and 1925 respectively (Khin 1957, Balon, 1967a, Holcík, 1995b, Hensel \& Holcík 1997). 
Table 2. Species richness (S), species diversity ( $\mathrm{H}^{\prime}$; calculated with natural logarithms) and equitability $(\mathrm{J})$ of the fish communities in different types of water bodies of the Slovak segment of the Danube river. Data for the main channel are own, those for the arm éofín and Trstená are recalculated (natural logarithms instead the decadic ones) from Holcík (1998 a), for Little Danube and arms between the villages Sap and Medvedov calculated from Miöík (1957) and Bél (1962), respectively.

\begin{tabular}{llcccc}
\hline Habitat & Location (river kilometer) & Year & S & H' & J \\
\hline Eupotamon & main channel (1730-1851) & $1992-1995$ & 29 & 1.95 & 0.58 \\
Eupotamon & Little Danube (above Kolárovo) & $1954-1955$ & 21 & 1.84 & 0.61 \\
Parapotamon & arm Žofin (1836) & $1969-1973$ & 28 & 1.67 & 0.53 \\
Parapotamon & Sap-Medved’ov (1805-1810) & 1957 & 22 & 1.58 & 0.51 \\
Plesiopotamon & Trstená (1825) & $1981-1989$ & 27 & 1.36 & 0.44 \\
\hline
\end{tabular}

The stellate sturgeon, Acipenser stellatus Pallas, 1771 has always been rare in this river section and individual specimens caught were therefore recorded. It migrated up to Komárno and also to Bratislava (Grossinger 1794, Fitzinger \& Heckel 1835, Kornhuber 1901). It probably also entered the mouth of the Morava River (Mahen 1927). The last specimen taken from the Danube at Komárno on February 20, 1926 measured $1.28 \mathrm{~m}$ and weighed $9.8 \mathrm{~kg}$ (Holcík 1995c).

The sterlet, Acipenser ruthenus Linnaeus, 1758, is the only sturgeon still common in this river section. Its occurrence and distribution declined between 1962 and 1978 but its catches increased until 1992. However, after the GRBS construction was put in operation, catches started to decrease again. It also re-appeared in the Slovak stretch of the Tisza River (Holcík 1995d) and in the lower course of the Morava River (Lusk \& Holcík 1998). Only its resident non-migratoryform now represents the Russian sturgeon Acipenser guel denstaedtii Brandt et Ratzeburg, 1833. It still occurs in this segment of the Danube, but it is extremely rare (Holcík 1995e, Hensel \& Holcík 1997).

The ship sturgeon, Acipenser nudiventris Lovetzky, 1828 , was found in the Danube River only as a resident, and not as diadromous form (Banarescu 1964, Manea 1966). It has always been rare in the entire Danube and completely disappeared from the Slovak segment of the Danube since the end of $19^{\text {th }}$ century if not earlier (Holcík 1995f).

Barbus peloponnesius Valenciennes, 1842 (syn. Barbus meridionalis not Risso, 1826, Barbus petenyi, Barbus meridionalis petenyi, Barbus carpathicus, Barbus balcanicus) is considered here to be a valid species inhabiting left tributaries of the Danube. Bar bus carpathicus and B. balcanicus recently described by Kotlík et al. (2002) as well as B. petenyi are only different populations of $B$. peloponnesius (see Economidis et al. 2003). They differ among themselves only in the combination of their mtDNA alleles. However, mtDNA data are sufficient for the analysis of relationships among populations but of their own accord are not suitable for deep relationships including the establisment of new species (Stepien \& Kocher 1997). The occurrence of B. peloponnesius in the Slovak stretch of the Danube was first recorded by Brtek \& Rotschein (1964), then questioned by Balon (1967) and finally confirmed by Zitnan (1972). Nevertheless, its occurrence should be considered as accidental and caused by specimens coming here from the left-hand tributaries, such as the Ipel and Hron rivers, where this species inhabits their foothill segments (Penáz 1995).

The minnow Phoxinus phoxinus and the spirlin $A l$ burnoides bipunctatus were rare species, found in this river segment only twice (Balon 1964, Žitnán 1972). No recent record of either species is known. However, their presence below and above the Gabcíkovo - Cunovo is presumed.

The Prussian carp, Carassius gibelio (Bloch, 1782), was first represented as a unisexual gynogenetic form (Balon 1962, Holcík 1980a, b). The first males appeared in 1992 and since that time, the males form the permanent part of its population. Although this species was already mentioned by Marsilius (1726) as native for the Danube, the population expansion since 1960 is probably caused not only by the decline of predators and the change of the hydrological regime of the river but also by the some introduced unknown strains of this species (Holcík \& Zitnan 1978, Holcík 1980b).

The crucian carp, Carassius carassius (Linnaeus, 1758 ) is considered to be the critically endangered species. Its abundance and biomass were already low in the 1960s (Balon 1967a) although before its density 
used to be high, especially outside the floodplain (Balon 1966). Ten years afterward it shows a sporadic occurrence and very low population density in the Danube River floodplain (Holcík \& Bastl 1976), in the Malý Dunaj, and in channels of the Zitný Ostrov region (Nagy \& Cerný 1992, Cerný 1999).

The declining commercial catch of Chondrostoma nasus (Linnaeus, 1758) as well as ichthyological research revealed a continuous deterioration of its populations. Formerly, the average frequency of this species in catches was around $10 \%$ (Balon 1967a), whereas in our experimental catches from 1992 to 1995 it was only $3.2 \%$.

The case of the original wild form of the common carp - Cyprinus carpio Linnaeus, 1758 or sazan, which is now extremely rare and belongs to the critically endangered species list, will be discussed later.

From four species of the genus Gobio, the Danubian gudgeon - G. uranoscopus (Agassiz, 1828) - probably disappeared from this river segment, as the last specimens were recorded by Zitnán (1972) downstream of Komárno in the 1970s. Gobio kesslerii Dybowski, 1862 is still present, but it is very rare, and since 1991 it was not recorded in any of the monitored localities on the area affected by the GRBS (Cerny 1995, 1999), and therefore it should be considered as a critically endangered species. Gobio albipinnatus Lukasch, 1933 is the most abundant species of this genus in all types of water bodies.

Three exotic «herbivorous» carps, i.e. the grass carp Ctenopharyngodon idella Valenciennes 1844, the bighead carp Hypophthalmichthys nobilis (Richardson, 1845) and the silver carp Hypophthamichthys molitrix ( Valenciennes, 1844) occurred all along the Slovak segment of the Danube, but mostly in the stretch Moca - Cenkov (r.km 1845 -1835). They were also found in the lower courses of the Váh, Hron and Morava rivers, sometimes over long distances. Their reproduction was not observed and their stock is composed of fishes escaped from fish farms and some inland water bodies situated in Hungary, Slovakia and Czech Republic.

Pelecus cultratus (Linnaeus, 1758) belongs to the group of critically endangered species. It is extremely rare and only occurs in the eupotamon and parapota mon sections of the Danube.

Pseudorasbora parva (Temminck \& Schlegel, 1842) is another exotic species discovered in this stretch of the Danube in 1976, where it penetrated from Hungary. Its occurrence in this segment of the Danube is insular and rather rare.
Rutilus meidingeri (Heckel, 1851) is an accidental invader from the upper course of the Danube and its occurrence is probably associated with floods. At present, however, the GRBS as well as upstream Austrian man-made lakes make its occasional occurrence impossible.

Rutilus pigus (La Cepède, 1803) is strictly confined to constantly flowing water, i.e., in the eupotamon and parapotamon sections. Its abundance seems to be severely limited by the quality of water.

The spined loach and the golden loach occurring in this segment of Danube belong to Cobitis elongatoides Bacescu \& Mayer, 1969 and Sabanejewia balcanica (Karaman, 1922) and not to Cobitis taenia Linnaeus, 1758 and Sabanejewia aurata (De Filippi, 1863) resp e c t i v e 1 y, as stated before (Kottelat 1997, Lusk \& Penáz 2000).

The European mud-minnow Umbra krameri Walbaum, 1792 was relatively abundant in the irrigation canals and some paleopotamal water bodies (Miš́ík 1965), but at the present time it belongs to the critically endangered species list, and can be found in one locality only.

The brown trout from the Danube belongs to the species Salmo labrax Pallas, 1814 (Holcík 1969, 2002a, Kottelat 1997). The resident forms the brook trout and the lake trout inhabit the Danube and its tributaries. They were relatively common over the entire Slovak segment of the Danube and the last verified records indicating 330-491 $\mathrm{mm}$ in fork length and a weight of 510-1870 g - were caught below Gabcíkovo (r. k m 1820) in 1993-1995.

Exotic salmonids, the rainbow trout Oncorhynchus mykiss ( Walbaum, 1792) and the brook trout Salveli nus fontinalis (Mitchill, 1814), were occasionally found especially in the main channel. Most likely, they penetrate into the Danube from some tributaries where the juveniles are stocked, or from some fish farms.

The huchen, Hucho hucho (Linnaeus, 1758), occurs over the entire Slovak Danube, and also in the lower part of the Morava River. Its catches are rare and the species is critically endangered both in the Danube and Slovakia generally (Holcík 1996b, 2002a).

The grayling, Thymallus thymallus (Linnaeus, 1758), seldom occurs in the Slovak segment of the river. A recent record of a specimen measuring $340 \mathrm{~mm}$ in SL and weighing $660 \mathrm{~g}$ was caught at Cenkov (r.km 1730 ) in June 1993. It was probably washed down from the Váh River or from the Morava and Dyje rivers, where it occurs in their lower courses (Blahák 1980, Lusk 1995). 
From two coregonids recorded in this segment of the Danube, Coregonus peled (Gmelin, 1788) is an exotic species planted into the Medvedovské arm (r.km 1807) and recorded in 1974 (Holcík et al. 1981). Five other specimens of whitefish discovered in the Slovak segment of Danube in 1970-1995 may be considered as native, although the species is very seldom and occurs accidentally. However, its proper determination is not clear yet. The first specimen, measuring $160 \mathrm{~mm}$ in fork length, with 32-gill rakers, was described as $\mathrm{Co}$ regonus lavaretus (Linnaeus, 1758) by Bastl \& Holcík (1971). Four specimens measuring $332-432 \mathrm{~mm}$ in fork length and weighing 510-1500 grams were caught during the tagging of fishes in this river segment below Cunovo and Gabcíkovo in 1992-1995. The number of their gill rakers varied from 32 to 36 which is in accordance with this count for Coregonus renke (Schrank, 1783), native from some Alpine lakes of the Danubian basin, and for which Kottelat (1997) found 30-45 gill rakers. The specimen of whitefish (measuring $164 \mathrm{~mm}$ in standard length) caught in the Danube at Vác in Hungary in 1960 also had 29 gill rakers (Berinkey 1960), and belonged to this species. However, Kottelat (l.c.) found a similar number of gill rakers for $C$. lava retus, C. albellus Fatio, 1890 and C. alpinus Fatio, 1885, which inhabit lakes belonging to different river basins. Nevertheless, the present population as well as all next possible discoveries of coregonids are associated with man-made lakes of the Upper Danube, where this species was and is continuously planted (Reichenbach-Klinke 1968, Kainz in lett. 16 September 1994).

The three-spined stickleback Gasterosteus aculeatus (Linnaeus, 1758) is native from the Danube, but its occurrence is insular. It seems to find suitable environmental conditions in some side channels, and in some localities its populations were exceptionally numerous (Hensel 1984). Contrary to the former opinion that aquarists have introduced this species (Balon 1967b, Bastl 1970, 1976, Holcík et al.1981), I suggest its possible translocation from the lower Danube in the ballast water of ships.

The population density of most percid species is rather low. Zingel zingel (Linné, 1766) is a critically endangered species, and Gymnocephalus baloni Holcík \& Hensel, 1974, G. schraetser (linnaeus, 1758), San der volgensis (Gmelin, 1788) and Zingel streber (Siebold, 1863) are vulnerable ones. With the exception of S. volgensis, all other species are predominantly confined to the eupotamon and seldom to the parapotamon.

Until 1990, the gobiids were represented only by the tube-nosed goby $P$ ro te ro rhinus marmoratus (Pallas, 1814). In 1994, Neogobius kessleri (Günther, 1861) was discovered in the Austrian part of the Danube (Zweimüller et al.1996) and in the same year in the Danube at Stúrovo (P. Bitter, pers.comm; Holcík 1998c). In 1999, N. gymnotrachelus (Kes s le r, 1857) has been discovered in the Danube at Bratislava (Kautman 2000, 2001). In 2001, N. fluviatilis (Pallas, 1814) was found along the left bank of Danube below Stúrovo and in the lower course of its tributary, the Hron River (Stránai \& Andreji 2001). Nevertheless, their presence here had to be much earlier and they were probably overlooked. Neogobius melanostomus (Pallas, 1814) was not discovered yet, but it certainly occurs also in the Slovak segment of the Danube, because it was already found in the Danube nearby Vienna (Wiesner et al. 2000), some 50 kilometres usptream. A potential species is N. iljini Vasil'eva \& Va s i l' e v, 1996, erroneously reported from the Roumanian segment of the Danube (Ráb, in lett. 18 December 2000) which is very similar to $N$. kessleri. The occurrence of $N$. syrman (Nordmann, 1840), reported from the Austrian segment of the Danube (Zweimüller et al. 2000) which appeared to be $N$. melanostomus (Wiesner et al. 2000) is a marine species, and its occurrence in the middle and upper courses is highly improbable (Holcík 2002b).

\section{Migrations}

To assess the effect of damming on fish migrations, an extensive fish tagging was performed from 1992 to 1995. The fishes were tagged and released in the river between Cenkov (r.km 1735) and the Cunovo weir ( r.km 1852), i.e., downstream of the dammed river stretch. Altogether, 6274 fish specimens belonging to 29 species were tagged by the FLOY TA $\mathrm{G}^{\circledR}$ anchor tags. From the results which will be published elsewhere, until 2002 when the last tagged fish returned, no tagged individual was detected above the Gabcíkovo dam, the Cunovo weir and/or in the anabranches in this region. This is unequivocal evidence that the Gabcíkovo dam and the Cunovo weir, along with weirs built in anabranch system, represent insurmountable obstacles for any species of fish. Our results also revealed that downstream of the GRBS all fish species including the white bream (Blicca bjoerkna) performed migrations within the Danube, and also between the Danube and its tributaries.

\section{Reproduction particularities}

With regard to appropriate water temperature, which is higher in the flooded floodplain, plesiopotamon and paleopotamon anabranches, and lower in the main channel and parapotamon side arms, the spawning period for particular fish species was different. During the spring flood two consecutive groups of fish reprodu- 
ced. The first group included Esox lucius, Leuciscus leuciscus, Gymnocephalus cernuus, G. baloni, G. schraetser and Aspius aspius. Their spawning occurred at temperatures ranging from 6 to $10{ }^{\circ} \mathrm{C}$. The second group reproduced at water temperature around $10-14{ }^{\circ} \mathrm{C}$, and included Zingel zingel, Z. streber, Cho drostoma nasus, Abramis ballerus, A. sapa, Rutilus pi gus and Sander volgensis.

The fish group which reproduced during the period of the summer flood consisted of (sequentially arranged) Rutilus rutilus, Perca fluviatilis, Acipenser ruthe nus, Sander lucioperca, Leuciscus cephalus, L. idus, Barbus barbus, Vimba vimba, Abramis brama, Pelecus cultratus, Abramis bjoerkna, Carassius gibelio, Cypri nus carpio, Silurus glanis. The spawning water temperature for this group ranged from 11 to $23{ }^{\circ} \mathrm{C}$.

It has to be stressed that the spawning period of the above-mentioned species overlapped, and the water temperature range at the beginning and end of spawning for species reproducing in spring and in summer varied from 4 to $19{ }^{\circ} \mathrm{C}$ and from 5 to $24{ }^{\circ} \mathrm{C}$, respectively.

\section{Fish catch statistics}

The mean annual recreational fish catch before the start of the GRBS construction and damming during the period 1961-1979 amounted to 102.7 metric tons (MT). The catch was composed of 47.4 MT $(46.1 \%)$ of the economically preferred species: Cyprinus car pio, Esox lucius, Sander lucioperca (and S. volgensis), Aspius aspius, Tinca tinca, Silurus glanis, salmonids (mostly Salmo labrax, rarely O n c o rhynchus mykiss, Salvelinus fontinalis and Hucho hucho), Anguilla an guilla, Ctenopharyngodon idella, Hypophthalmichthys molitrix and $H$. nobilis. According to reproductive guilds composition, $43.5 \mathrm{MT}(42.4 \%)$ consisted of phytophils and 23.5 MT (22.9\%) of lithophils.

During the construction of the GRBS (1980-1992) the total fish catch continuously decreased. The mean annual fish catch in this period was 79.4 MT, i.e. 22.7 $\%$ less than the catches recorded before the beginning of the GRBS construction. This decrease which was salient since 1984 , is statistically significant $(\mathrm{P}<0.01)$. The highest fall was recorded for the catch of economically preferred fish, phytophils, and lithophils. Their catch dropped to 23.9, 20.6 and 9.8 MT, i.e., they decreased by 49.5, 52.6 and $58.6 \%$ respectively. Except for Abramis brama, the correlation was significant $(\mathrm{P}<0.05)$ or highly significant $(\mathrm{P}<0.01)$.

During the period 1993-1996, after the GRBS was built and put in operation, the mean annual catch dropped to $26.8 \mathrm{MT}$, i.e., it was by $73.9 \%$ less than in the period 1961-1979. Catches showed high fluctuations, and regression curves for particular species (which I do not introduce) significantly differed among themselves. Gradual decreases were recorded in the catch of Esox lucius, Sander lucioperca and Abramis brama, while the total fish catch curve, the catch of economically preferred species, and also the catch of Chondro stoma nasus and Leuciscus cephalus were convex, showing an increase until 1982-1984, and then a continuous drop.

\section{Endangered fish species and reasons of changes}

Considerable changes occurred during the past 100 years, owing to hydraulic engineering projects (riverbank fortification and heightening, cutting off sidearm mouths, damming), overfishing and pollution. Using the IUCN classification and considering the continuously recorded, anticipated and/or still occurring but not recorded species in the past 30 years, the situation is as follows (Table 1).

Three species (Acipenser huso, Acipenser nudiven tris, Acipenser stellatus) and one form (diadromous race of Acipenser gueldenstaedtii), or $6.6 \%$ became extinct, twelve species (19.6\%), including Eudontomy zon mariae, the resident form of Acipenser gueldens taedtii, Carassius carassius, wild form (sazan) of $C y$ prinus carpio, Gobio kesslerii, G.uranoscopus, Pele cus cultratus, Rutilus pigus, Misgurnus fossilis, Umbra krameri, Hucho hucho and Zingel zingel now belong to the the critically endangered species (CR). Seventeen $(27.9 \%)$ fish species are considered as vulnerable (VU), and six other ones $(9.8 \%)$ are data deficient (DD).

As an example of dramatic changes in the fish fauna composition, the cases of the sazan i.e. the wild form of the carp (Cyprinus carpio), and the nase (Chondro stoma nasus) may be introduced. The sazan was common in the Danube and the lower courses of its larg e tributaries and was also commercially harvested four decades ago. From the data by Miš́k (1957) and Bél (1962), one may find that in haul seine catches, both in the Slovak and Hungarian side of this segment of the Danube, sazan counted $1.1 \%$ of the total number of fishes caught, or 3.4-10.1\% of the total fish catch weight (Tóth 1960, Balon 1967a). At the present time, however, its distribution is restricted to some parts of the main channel of the Danube and its population is extremely small. Among 6274 fish taken, tagged, and released in the Danube between Gabcíkovo and Cunovo in 1992-1995, only $18(0.28 \%)$ were carp, and only one $(0.016 \%)$ was a typical sazan. The sazan is now at the edge of its extinction. The main reason is that af- 
ter the construction of the GRBS, the inland delta of this stretch of the Danube vanished and the sazan lost its spawning grounds. The loss of the reproductive possibilities of this form due to the regulation measures is the main reason of the catastrophic decline of its catches in the whole Danube (Ivanov 1978). Another potential danger is the ignorance of the Slovak Anglers Union Council, responsible for the fishery in all Slovak rivers, which decided to stock the Danube with the Ropshin lineage of carp. This form is a hybrid of Cyprinus carpio (Galicia race) and the Amur sazan - Cyprinus haematopteru s Temminck \& Schlegel, 1842 from the Amur River. It has been bred in Russia since 1930 for the stocking of ponds in the northern regions (Kirpichnikov 1958, Pokorný et al. 1995). Fortunately, the attempts to save the wild carp are now realised in both the Slovak and the Czech Republic (Lusková et al. 2000).

Another example of the consequences of the Danube regulation can be seen on the nase Chondrostoma na sus, a lithophilous species. Although it is reproductively not depending on the floodplain, the floodplain existence is necessary for the survival and rearing of larvae and juveniles. According to several data obtained over several years with the same fishing gear (haul seine $150-300 \mathrm{~m}$ in length, $5.2 \mathrm{~m}$ in depth, mesh size $35 \times 35$ - 40x40 mm), by both fishermen and our investigators, the mean abundance of the nase catch in the 1960s was $10 \%$ (Balon 1967a), but in 1992-1995 it dropped to $3.2 \%$. As it was found by Keckeis et al. (1996), the nase spawning in the Danube occurrs in some habitats only, i.e., near banks with gentle slopes, over bottoms covered with uniform size gravel, and under relatively strong water current velocities. However, the larvae and juveniles survival and growth depend on the presence of suitable (i.e. flood protected) habitats (Hofer $\&$ Kirchhofer 1996). Following numerous observations (e.g. Lelek 1987, Pavlov et al.1994, Kirchhofer 1996, Penczak 1996, Peñáz 1996) hydraulic engineering is the main factor responsible for the decline of the nase both in the Danube and in other European rivers.

Changes in fish catch reflect the changes in fish communities and populations. The Gabcíkovo case confirmed the well known effects of river damming and engineering works upon fish and fisheries (e.g., Goldsmith \& Hildyard 1984, 1984a, 1986, 1992, Welcomme 1985, Holcík 1990, 2001, Jankovic 1996, Ribeiro et al. 1995, Petrere 1996). The main effects of river regulation (which first affected the hydrological regime) were the loss of the pulse effect of floods, the modification of the chemical composition and thermal regime of the water, and the blocking of fish migration.
Moreover, the loss of floodplain resulted in the catastrophic decline of both habitats and ecotones. It also has to be pointed that: 1) the hydrochemical dynamics controls the nutrient concentration over the entire floodplain, 2) the dependence of fish upon the structural and functional characters of the terrestrial-aquatic ecotones is complex and far-reaching, and 3 ) the effect of such large amount of different factors is synergistic (Hein et al. 1996, Schiemer et al. 1995 and literature herein).

The importance of floods in the inland delta on fish and fisheries is well documented by the analysis of the correlation between the hydrological regime and both the fish density and the fish catch. In the Slovak segment of the Danube, within the period 1951-1975, the increase of the mean annual water level by one centimetre enlarged the mean annual commercial fish catch by $500 \mathrm{~kg}$ in the corresponding year, and by $300 \mathrm{~kg}$ in the next one (Holcík \& Bastl 1974, 1975, 1977). This was also due to the extremely high ecological fish production, which surpassed the amount of the food produced in the floodplain. In addition, as documented elsewhere (Holcík 1996a), the floodplain fish production is composed of two parts: one is represented by the production created within the floodplain, while the other is represented by fish migrating and/or washed down to the floodplain from the main channel and the upstream segments of the river.

The main negative impact of the Danube damming upon the fish and fisheries is the loss of the functional inland delta. The original floodplain ecosystem was replaced by the artificial system of mutually isolated or only marginally linked habitats. As a result, there was a loss of feeding habitats, and a lower food supply due to the decrease of the abundance and biomass of food o rganisms. Spawning, wintering, and refuge habitats for fish also decreased and/or were lost, not only in the floodplain, but also in adjacent upstream and downstream river sections.

\section{Proposals for the improvement of the inundation environment}

Before the projecting and realisation of any measures aiming to mitigate the effect of the Danube damming by the GRBS on the former floodplain, it is necessary to consider two principal factors governing the high species diversity, ecological production and fish catch in any floodplain rivers: 1) the connection of the side-arms system with the main channel enabling the bilateral fish migrations, and 2) the seasonal discharge pulsation and seasonal flooding of the floodplain. 
To ensure the bilateral fish migration, it is necessary to build functional fish ways between the side-arms and the main channel, and between particular parts of the arms. The fish way can be constructed as bypass canals (biocorridor), or as rocky-chutes. Both types of fish ways (with which in our country there is no experience of how to construct them) have to allow migration of different species at different size, i.e., they have to be universal. Environmental requirements for the fish ways construction are well known (Holcík \& Bastl 1996, Holcík et al. 1992, 2001). Details, including the technical ones were published in Pavlov (1979, 1989), Clay (1995), and Jungwirth et al. (1998).

As mentioned above, there were two floods per year, in spring and in summer. The migration of particular fishes coincided with both floods. The optimal situation should be that both floods cover the entire floodplain up to the big river dike. The start, culmination, and fading away of floods should simulate the situation which existed before the GRBS construction.

It is important to save the course of the filling and then the draining of the flooded area. The filling curve may be steeper, i.e., the flooding can be shorter. How e v e $r$, the draining curve should be more flat - the floodplain draining has to be longer and gradual, in order to secure the hatching of eggs laid, and the emigration of the larvae and juveniles. Particular data dealing with the flood terms should be in accordance with the water thermal regime. During spring flood, the filling should start at the temperature of the filling water $\left(4{ }^{\circ} \mathrm{C}\right)$, and draining should start when water in the floodplain rises to $15{ }^{\circ} \mathrm{C}$. During summer flood, the filling should start at the temperature of the filling water $\left(15^{\circ} \mathrm{C}\right)$, and draining should start when the water temperature in the floodplain ascends to $20^{\circ} \mathrm{C}$.

\section{Summarizing}

Seventy-four fish species were found in the SlovakAustrian, Slovak and Slovak-Hungarian stretch of the Danube River, the occurrence of two species is anticipated. Sixty-one species are native $(80.3 \%), 11$ species were introduced exotic ones (14.5\%), and 5 (6.6 $\%)$ or $7(9.2 \%)$, if supposed that two new invading species are anticipated, are recent invaders. Three (3.9 $\%$ ) species and one form (diadromous form of Acipen ser gueldenstadtii) became extinct; the presence of other 7 species $(9.2 \%)$ was not recorded during past 20 years. After the construction of the Gabcíkovo River Barrage system in October 1992 twelve species, including Eudontomyzon mariae, the resident form of Acipenser gueldenstaedtii, Carassius carassius, wild form (sazan) of Cyprinus carpio, Gobio kesslerii, G. uranoscopus, Pelecus cultratus, Rutilus pigus, Mis gurnus fossilis, Umbra krameri, Hucho hucho and Zin gel zingel now belong to the critically endangered species (CR). Seventeen fish species are considered as vulnerable (VU) and four other ones are data deficient (DD). The mean annual recreational fish catch from 1993 to 1996 dropped by $73.9 \%$ in comparison with the mean annual recreational fish catch during the 1961-1979 period. The main reason is the loss of the functional inland delta, which was replaced by the artificial system of mutually isolated or only marginally linked habitats. To improve the situation it is proposed to restore the bilateral connection of the main channel with the side-arms, to ensure the fish migration between the main channel and the side arms, and to simulate the original flooding of the floodplain.

\section{Acknowledgements}

This work has been supported by the Scientific Grant Agency of the Slovak Academy of Sciences G AV 1079, VEGA 6305 and VEGA 5502. For valuable information and some literature supply I am deeply indebted to Dr. Harald Ahnelt, Dr. Tibor Erös, Dr.Theodore Nalbant, Dr. Irene Zweimüller, Dr. Joseph Wanzenböck and Mgr. Ján Kautman. For technical assistance during the preparation of this paper, especially for the preparation of the Figure 1, I am indebted to my colleague Dr. Milos Vater and for linguistic assistance for my daughter- i n - l a w, Katalin Bertényi, M.Sc.

\section{References}

Ahnelt H., Banarescu P., Spolwind R., Harka A. \& Waidbacher H. 1998. - Occurrence and distribution of three gobiid species (Pisces, Gobiidae) in the middle and upper Danube region examples of different dispersal patterns. Biologia, Bratislava, 53: 665-678.

Balon E.K. 1962. — Ökologische Bemerkungen (ber die Standorten der Donaufische mit einer Beschreibung des Fundes des Carassius auratus gibelio (Bloch, 1783) und Alburnoides bipunctatus (Bloch, 1782). Vestník cs.Spol.zool, 26 : 331-351.

Balon E.K. 1964. - O noua contributie la cunoasterea locurilor de stationare a pestilor la pinteni. Descrierea speciei Phoxinus phoxi $n u s$, un nou peste în sectorul cercetat al Dunarii. (Ein weiterer Beitrag zur Kenntnis der Fischstandorte in den Buhnen. Beschreibung der Phoxinus phoxinus - Gattung, ein neuer Fisch des erforschten Donauabschnitts). Hydrobiologia, 5 : 187-196. (in Rumanian with German summary).

Balon E.K. 1966. — Ichtyofauna ceskoslovenského úseku Dunaja (Fishfauna of the Czechoslovak segment of the Danube). Pages 270-323 in Limnológia ceskoslovenského úseku Dunaja. Mucha V. \& Dub O. (eds.) Vydavatelstvo SAV, Bratislava. (in Slovak).

Balon E.K. 196a. - Vývoj ichtyofauny Dunaja, jej súcasn'y stav a pokus o prognózu dalsích zmien po výstavbe vodných diel (Evolution of the Danube River fishfauna, its present status and an attempt to predict its further changes after the construction of the water works). Biologické práce SAV, 131 : 7-121 (in Slovak with English summary). 
Balon E.K.1967b. - Koljuska G a s t e rosteus aculeatus Linnaeus, 1758 v Dunaji pri Bratislave (Three-spined stickleback Gasterosteus aculeatus Linnaeus, 1758 in the Danube near Bratislava). Ac.Rer.Natur.Mus.Nat.Slov., Bratislava, 13-2 : 127-134 (in Slovak with English summary).

Balon E.K. \& Holcík J. 1999. — Gabcíkovo river barrage system: the ecological disaster and economic calamity for the inland delta of the middle Danube. Env. Biol. Fish., 54 : 1-17.

Bănărescu P. 1964. - Pisces-Osteichthyes. Fauna Republicii Popu lare Romine. Vol.13. Editura Acad. Republicii Populare Rom(ne; Bucuresti, 962 p. (in Rumanian).

Bastl I. 1970. — Dalsí nález pichlavky Gasterosteus aculeatus Linnaeus, 1758 v Dunaji pri Bratislave (Further finding of the threespined stickleback in the Danube near Bratislava). Ac. Rer. Natur. Mus. Nat. Slov., Bratislava, 16-2 : 201-202. (in Slovak with Russian summary)

Bastl I. 1976. - Dalsí doklad o výskyte pichlavky (Gasterosteus aculeatus Linnaeus, 1758) v inundacnej oblasti Dunaja na ceskoslovenskom 'zemí (Further record of the three-spined stickleback - Gasterosteus aculeatus Linnaeus, 1758 in the floodplain of the czechoslovak stretch of the Danube river). Biológia (Bratislava), $31: 885-887$

Bastl I. \& Holcík J. 1971. - First find of the whitefish - Coregonus lavaretus (Linnaeus, 1758) in the Danube River. Vestník cs. Spol. zool., 35 : 81-84.

Bastl I., Vra n o v s ký M., Cernýy J., Holcík J., Kirka A., Kovácik L., Nagy S., Sporka F., Stefková E. \& Tomajka J. 1990. — Biocenó zy ramien ceskoslovenského úseku Dunaja v oblasti výstavby du najsk'ych vodných diel (Biocenoses of the Czechoslovak segment of the Danube within the area of the Danubian water works construction). Final report from the project VI-4-6/03. Institute of Fishery Research and Hydrobiology, Bratislava, 55 pp. (in Slovak).

Bél J. 1962. — Lov rýb zát'ahovou sietou na Dunaji v Palkovicove (The haul seine fishing on the Danube River near Palkovicovo). Práce Laboratória rybárstva, 1 : 199-224. (in Slovak).

Berinkey L. 1960. — Ichthyological notes I. Vertebrata Hungarica, 2: $11-18$

Blahák P. 1980. — On the occurrence of the grayling, Thymallus thymallus in the lower part of the Morava river. Vestník cs.Spol.zool., 44 : 264-267.

Brtek J. \& Rotchschein J. 1964. — Ein Beitrag zur Kentnis der hydrofauna und des Reinheitszustandes des tschechoslowakischen Abschnittes der Donau. Biologické práce SAV, $10: 62$ pp.

Cellot B. 1996. - Influence of side-arms on aquatic macroinvertebrate drift in the main channel of a large river. F reshwat. Biol., 35: 149-164.

Clay C.H. 1995. - Design of Fishways and Other Fish Facilities, Boca Raton, Florida, USA: CRC Press., 128 p.

Cummins K.W. 1972. - What is a river ? A zoological description. Pages 33-52 in Oglesby R.T. et al.(eds.). River ecology and man. Academic Press; New York.

Cerný J. 1995. - Monitoring of ichthyocenoses in the Slovak part of the Danube inland delta before and after operation start of the Gabcíkovo barrage system. Pages 203-210 in Mucha I. (ed.) Gabcíkovo part of the hydroelectric power project. Environmen tal impact review. Faculty of Natural Sciences, Comenius univers i t y, Bratislava and Plenipotentiary of the Slovak Republic for construction and operation of Gabcíkovo-Nagymaros hydropower Project, Bratislava

Cerný J. 1999. - Monitoring of ichthyocenoses in the Slovak stretch of the Danube and in its side arms. Pages 201-216 in Mucha I. (ed.) Gabcíkovo part of the hydroelectric power project. Environ mental impact re vi ew. Faculty of Natural Sciences, Comenius
University Bratislava, Slovakia and Plenipotentiary of the Slovak Republic for Construction and Operation of Gabcíkovo-Nagymaros Hydropower Scheme; Bratislava.

Cerný J. \&. Kvaszová B. 1999. — Impact of the Gabcíkovo project on fish fauna - data review. Pages 217-226 in Mucha I. (ed.) Gabcikovo part of the hydroelectric power project. Environmental impact review. Faculty of Natural Sciences, Comenius University Bratislava, Slovakia and Plenipotentiary of the Slovak Republic for Construction and Operation of Gabcíkovo-Nagymaros Hydropower Scheme; Bratislava.

Economidis P.S., Š̉ic V.M. \& Bănărescu P.M. 2003. — Barbus pe loponnesius Valenciennes, 1842. Pages 301-337 in Banarescu P.M. \& Bogutskaya N.G. (eds.) The Freshwater Fishes of Europe. Vol.5/II. Cyprinidae 2/II. AULA-Verlag; Wiebelsheim.

Fitzinger L.J. \& Heckel J. 1835. — Monographische Darstellung der Gattung Acipenser. Ann.Wiener Mus.Nat., 1: 269-326.

Goldsmith E. \& Hildyard N. 1984. - The politics of damming. The Ecologist, 14 : 221-231.

Goldsmith E. \& Hildyard N. 1984a, 1986, 1992. — The social and e $n v$ i ronmental effects of large dams. Vol.1 Overview (1984), Vol.2 Case studies (1986), Vol.3 A review of literature [1992, Trussel D. (ed.)]. Wadebridge Ecological Centre, Camelford, 346, 331 and 243 p., respectively.

Grossinger J.B. 1794. - Universa historia physica Regni Hunga riae secundum tria regna naturae digesta. Regni animalis pars III. Ichthyologia, sive historia piscium, et amphibiorum. S.P. Weber; Posonii et Comaromii. xiv +400 p.

Heckel R. \& Kner R. 1858. - Die Süsswasserfische der Österre $i$ chischen Monarchie mit Rücksicht an die angrezenden Länder. W. Engelmann, Leipzig, 338 p.

Hein T., Schagerl M., Heiler G. \& Schiemer F. 1996. — Chlorophyll- $a$ and hydrochemical dynamics in a backwater system of the Danube, controlled by hydrology. Arch.Hydrobiol. Suppl.113, Large Rivers, 10: 1-4.

Hensel K. 1984. — Hromadný výskyt pichlavky Gasterosteus acu leatus Linnaeus, 1758 na éitnom ostrove (Mass occurrence of the three spined stickleback $G$ a s te rosteus aculeatus Linnaeus, 1758 in the éitný ostrov). Spravodaj múzea 8 : 62-66. (in Slovak).

Hensel K. \& Holcík J. 1997. — Past and current status of sturgeons in the upper and middle Danube River. Env. Biol. Fish., 48 : 185200.

Herman O. 1887. — A Magyar halászat könyve. I.II. K.M. Természettudományi Társulat, Budapest. 860 p.

Hofer K .\& Kirchhofer A. 1996. - Drift, habitat choice and growth of the nase (Chondrostoma nasus, Cyprinidae) during early life stages. Pages 269-278 in Kirchhofer A. \& Hefti D. (eds.) Conser vation of endangered freshwater fish in Europe. Birkhäuser Verlag, Basel-Boston-Berlin.

Holcík J. 1969. - A note on the occurrence and taxonomy of brown trout - Salmo trutta Linnaeus, 1758 in the Danube River. Vestník cs. Spol. zool., 33 : 223-228.

Holcík J. 1980a. - Possible reason of the expansion of Carassius auratus (Linnaeus, 1758) (Teleostei, Cyprinidae) in the Danube river basin. Int.Revue ges. Hydrobiologie, 65 : 673-679.

Holcík J. 1980b. - Carassius auratus (Pisces) in the Danube River. Acta Sci. Natur. Acad. Scient. Bohemoslov. Brno 14 (nova series), (11) : 1-46.

Holcík J. 1990. - Effects of hydraulic engineering on habitat and fish community in river anabranches of the middle Danube. Pages 14-24 in Management of freshwater fisheries. Van Densen W.L.T., Steinmetz B. \& Hughes H.R. (eds.) Proceedings of a symposium organized by the European Inland Fishery Advisory Commission, Göteborg, Sweden, 31 May-3 June 1998, Pudoc, Wageningen. 
Holcík J. 1995a - 2.druh Eudontomyzon mariae (B e rg, 1931) (2.species Eudontomyzon mariae (B e rg, 1931). Pages 84-90 in Baruš V. \& Oliva O. (eds.) Mihulovci Petromyzontes a ryby Os teichthyes. Fauna CR a SR 28/1. ACADEMIA, Praha (in Czech with English summary).

Holcík J., 1995b - 1. druh Huso huso (Linnaeus, 1758) (1. Species Huso huso (Linnaeus, 1758)). Pages 374-38 in Baruš V. \& Oliva O. (eds.) Mihulovci Petromyzontes a ryby Osteichthyes. Fauna CR a SR 28/1. ACADEMIA, Praha. (in Czech with English summary).

Holcík J. 1995c - 2.druh Acipenser (Gladostomus) stellatus Pallas, 1771 (2. species Acipenser (Gladostomus) stellatus Pallas, 1771)). Pages 381-384 in Barus V. \& Oliva O. (eds.) Mihulovci Petromyzontes a ryby Osteichthyes. Fauna CR a SR 28/1. ACADEMIA, Praha. (in Czech with English summary).

Holcík J. 1995d. - 3. Druh Acipenser ruthenus Linnaeus, 1758 (3. Species druh Acipenser ruthenus Linnaeus, 1758). Pages 381-384 in Baruš V. \& Oliva O. (eds.) Mihulovci Petromyzontes a ryby Os teichthyes. Fauna CR a SR 28/1. ACADEMIA, Praha. (in Czech with English summary).

Holcík J. 1995e. - 4.druh Acipenser gueldenstaedti Brandt, 1833 (4. Species) Acipenser gueldenstaedti Brandt, 1833). Pages 391397 in Baruš V. \& OlivaO. (eds.) Mihulovci Petromyzontes a ryby Osteichthyes. Fauna CR a SR 28/1. ACADEMIA, Praha. (in Czech with English summary).

Holcík J. 1995f. - 1. Druh Acipenser (Lioniscus) nudiventris Lov e t z k y, 1928 (1. Species Acipenser (Lioniscus) nudiventris Lovetzky, 1928). Pages 379-381 in Barus' V. \& V. Oliva O. (eds.) Mi hulovci Petromyzontes a ryby Osteichthyes. Fauna CR a SR 28/1. ACADEMIA, Praha. (in Czech with English summary).

Holcík J. 1995g. - Geographic distribution of lampreys (Petromyzontiformes) in the Middle and Lower Danube (between Austria and the Black Sea). Fischökologie, $8: 23-30$.

Holcík J. 1996a. - Ecological fish production in the inland delta of the Middle Danube, a floodplain river. Env. Biol. Fishes, 46 : 151165.

Holcík J. 1996b. — Prezije rok 2000 ? (Does it survive beyond the year 2000?) Pages 69-80 in Kadlecík J. (ed.) Turiec 1996. Ministerstvo ûivotného prostredia SR, Bratislava.

Holcík J. 1998a. — Druhová diverzita ichtyocenóz niektor'ych vÙd slovenského 'seku Dunaja (Fish community diversity of some water bodies in the Slovak segment of the Danube River). Pages 51-55 in Lusk S. \& Halacka K. (eds.) Biodiverzita ichtyofauny Ceské republiky II. Ustav biologie obratlovcu AV CR, Brno. (in Slovak with English summary).

Holcík J., 1998b. - Impact of the Gabcíkovo water works construction and operation on the recreational fishery in the Slovak segment of the Danube river. Pages 51-55 in Rauta M., BacalbasaDobrovici N., Vasilescu G. \& Oprea L. (eds.) Managementul pes carilor in bazinul Dunarii, rezumalele extinse ale lucrarilor pre zentate la Simpozionul International Aquarom ' 98 (Fisheries ma nagement in the Danube river basin, extended bastracts of contri butions presented at the international symposium Aquarom '98), Galati, Romania 18-22 May 1998.

Holcík J. 1998c. - Ichtyológia (Ichthyology). Príroda, Bratislava, 310 p. (in Slovak).

Holcík J. 2001. - The impact of stream regulations upon the fish fauna and measures to prevent it. Ekológia (Bratislava), 20 : 250262.

Holcík J. 2002a. - Taxonomy and conservation problems of the native salmonids (Pisces: Salmonidae) in the Danube river system: a review. Acta Soc. Zool. Bohem., 66 : 177-188.

Holcík J. 2002b. - Nase býcky a ako ich rozlísit (Our gobies and how to distinguist them). Pages 73-78 in Lusk S. \& Halacka K. (eds.) Biodoverzita ichtyofauny CR IV./stav biologie obratlovcu AV CR, Brno (in Slovak with English summary).

Holcík J. 2003. - Note to the occurrence of the Ukrainian lamprey [Eudontomyzon mariae ( B e rg, 1931)] in the Middle Danube. Biológia, Bratislava, 58 : 241-244.

Holcík J., Bănărescu P. \& Evans D. 1989. - A. General introduction to fishes. Pages 18-147 in Holcík J.(ed.) The Freshwater Fishes of Europe. Vol.1, Part II. General Introduction to Fishes. Acipense riformes. AULA-Verlag; Wiesbaden.

Holcík J.\& Bastl I. 1974. Vliyanie gidrologicheskikh izmenenii na ikhtiotsenoz dunaiskogo rukava i godovoi obshchii vylov ryb v chekhoslovatsko-vegerskom uchastke Dunaya (Influence of the hydrological changes upon the fishfauna of the Danubian side arm and the total fish catch in the czechoslovak-hungarian stretch of the Danuibe river). Pages 6-40 in Volcek L., Dobrai L., Georgiev N., Pesic Z., Stonescu V. \& Eventov Z. (eds.). Materialy XVI.Sessii Smeshannoi komissii po primeneniyu Soglashenya o rybolovstve v vodakh Dunaya, Bratislava. (In Russian).

Holcík J. \& Bastl I. 1975. — Einfluss der Veränderungen des hydrologischen Regimes der Donau auf den Fishfang. Pages 345-357 in 18. Arbeitstagung der Internationale Arbeitsgemeinschaft Don mauforschung. 14.-20. September 1975. Wissenschaftliche Kurzreferate, 1 . Tei. Regensburg.

Holcík J. \& Bastl I. 1976. - Ecological effects of water level fluctuation upon the fish populations in the Danube river floodplai in Czechoslovakia. Acta Sc. Nat .Brno 10 : 1-46.

Holcík J. \& Bastl I. 1977. — Predicting fish yield in the Czechoslovakian section of the Danube river basedon the hydrological regime. Int. Rev. ges. Hydrobiologie, 62 : 523-532.

Holcík J. \& Bastl I. 1996. — Súčasný stav ichtyofauny rieky Oravy (Present status of the fish fauna in the Orava River). Zborník Oravského múzea, 13 : 113-125 (in Slovak).

Holcík J., Bastl I., Ertl M. \& Vranovský M. 1981. — Hydrobiology and ichthyology of the Czechoslovak Danube in relation to predicted changes after the construction of the Gabcíkovo-Nagymaros River Barrage System. Práce Lab. Rybár. Hydrobiol., 3 : 19158.

Holcík J., Bastl I., Cambel B., Lisický M.J., Matecný I., Pisút P. , Uhercíková E. \& Vr a n o v s ký M. 1992. — Vnútrozemská delta Dunaja - jej funkcie, význam a kritériá pre úpravné zásahy (Inland delta of the Danube - its function, importance and criteria for tretment actions). Vodní hospodárství, 42 : 132-137 (in Slovak)

Holcík J. \& Delic A. 2000. - New discovery of the Ukrainian brook lamprey in Croatia. J. Fish Biol., 56 : 73-86.

Holcík J. \& Renaud C.B. 1986. - Eudontomyzon mariae (Berg, 1931). Pages 163-185 in Holcík J.(ed.) The freshwater fishes of Europe. Vol.1, Part I. Petromyzontiformes. AULA-Verlag, Wiesbaden.

Holcík J., Stráñai I., Zontág M. \& Hensel K., 2000. — Ryby, rybárstvo a plánovaná výstavba sústavy malých vodných elektrární na Váhu nad Kralovanmi (Fishes, fishery and the planned costruction of the small hydropower station system in the Váh river above Kralovany). Ochrana prírody, Banská Bystrica, 18 : 161-184 (in Slovak with English summary).

Holcík J., Stráňai I. \& Andreji J. 2001. — Mihule v Dunaji ešte žijú (Lamprey still live in the Danube River). 7.Feriancove dni 2001. Page 12 in Kautman J., Némethová D. \& Kovác V. (eds.), 7. Zoo logická konferencia Feriancove dni 2001. Zborník abstraktov. Slovenské národné múzeum - Prírodovedné múzeum, Bratislava.

Holcík J. \& éitnan R. 1978. - On the expansion and origin of $\mathrm{Ca}$ rassius auratus in Czechoslovakia. Folia Zool., 27: 278-288.

Illies J. \& Botosaneanu L. 1963. Problemes et méthodes de la classification et de la zonation écologique des eaux courrantes, considerées surtout du point de vue faunistique. Mitt. int. Verein. theor. angew. Limnol.12 : $57 \mathrm{p}$. 
Ivanov L. 1978. - Retsesiya na b'lgarskite ulovi ot dunavski sharan (Cyprinus carpio L.) i merki po okhrana i v'sproizvodstvo na zapasite mu (Rezession in den bulgarischen Fängen von Donaukarpfen (Cyprinus carpio L.) und Massnahmen zu seinem Schutz). Pages 229-237 in.Rusev B.K \& Naidenov V. T. (eds.) Limnologiya na b'lgarskiya sektor na reka Dunav. Izd. na B'lgarskata akademiya na naukite, Sofiya.

Jankovic D. 1996. - Ichthyofauna of the Danube in the Djerdap area after the construction of the Iron Gate I hydroelectric power system. Acta Universitatis Carolinae, Biologica, 40, (1-2) : 123131.

Jepsen D.B. 1997. — Fish species diversity in sand bank habitats of a neotropical river. Env. biol. Fish., $49: 449-460$.

Jungwirth M., Schmutz S. \& Weiss S. 1998. — Fish migration and fish bypasses. Fishing News Books, Oxford, 440 p.

Junk W.J., Bayley P.B. \& Sparks R.E. 1989 - The flood pulse concept in river-floodplain system. Pages 110-127 in Dodge P.D. (Ed.) P roceedings of the International Large River Symposium. Can. Spec. Publ. Fish. Aquat. Sci.106.

Kautman J. 2000. - Tri nové druhy rýb na Slovensku (Three new fish species of Slovakia). Pages 29-36 in Lusk S. \& Halacka K. (eds.). Biodiverzita ichtyofauny CR III. Ustav biologie obratlovcu AV CR, Brno. (In Slovak).

Kautman J. 2001. - The first occurrence of Neogobius gymnotra chelus (Pisces, Gobiidae) in the Slovak Danube. Folia Zoologica, $50: 79-80$.

Keckeis H., Frankiewicz P. \& Schiemer F. 1996. - The importance of inshore areas for spawning nase Chondrostoma nasus (Cyprinidae) in a free flowing section of a large river (Danube, Austria). Arch. Hydrobiol., Suppl. 113, Large Rivers, 10 : 51-64.

Khin A. 1957. - A Magyar vizák története (The beluga history in Hungary). Mezgazdasági Mözeumi Fzetek 2 : 124 p. (in Hungarian).

Kirchhofer A. 1996. — Fish conservation in Switzerland - three case studies. Pages 135-145 in Kirchhofer A. \& Hefti D. (eds.) Conservation of endangered freshwater fish in Europe. Birkhäuser Verlag, Basel-Boston-Berlin.

Kirka A. 1997. - Atlas rýb vodného diela Gabcíkovo (Fish atals of the water work Gabcíkovo). PaRPRESS, Bratislava., 132 pp.

Kirka A. 1998. — Druhová rozmanitost r'yb Dunaja v oblasti VD Gabcíkovo (Species richness of fish in the area Gabcíkovo Water Work, the Danube River). Pages : 63-67 in Lusk S. \& Halacka K. (eds.) Biodiverzita ichtyofauny Ceské republiky II. Ústav biologie obratlovcu AV CR, Brno. (in Slovak).

Kirka A. 1999. - Ichthyofauna and fisheries of the Cunovo Reservoir. Pages 227-231 in Mucha I. (ed.) Gabcíkovo part of the hy droelectric power project. Environmental impact review. Faculty of Natural Sciences, Comenius University Bratislava, Slovakia and Plenipotentiary of the Slovak Republic for Construction and Operation of Gabcíkovo-Nagymaros Hydropower Scheme. Bratislava.

Kirpichnikov V.S. 1958. - Kholodostoikost' i zimoustoichivost' molodi karpa, sazana i ikh gibridov (Cool and winter resistance of the juveniles of the carp, the sazan and their hybrids). Trudy sove shchanii Ikhtiologicheskoi kommissi AN SSSR, 8 : 261-270. (in Russian).

Kornhuber G.A. 1863. — Bemerkungen uber das Vorkommen der Fische um Pressburg und an einigen anderen Orten Ungrans. Cor respondenzblatt der Vereins fur Naturkunde zu Pressburg, 2 (12) : 205-213.

Kornhuber G.A. 1901. - Zoologische Bemerkungen, 2. Vo m Scherg oder Sternahusen, Acipenser stellatus Pallas. Verhandlungen der Ve reins fr Natur- und Heilkunde zu Pre s s b u rg. N.F., 12: $32-33$.
Kotlík P., Tsigenopoulos C.S., Ráb P.\& Berrebi P. 2002. — Two new Barbus species from the Danube River basin, with redescription of B. petenyi (Teleostei: Cyprinidae). Folia Zool., 51 : 227-240.

Kottelat M. 1997. - European freshwater fishes. An heuristic checklist of the freshwater fishes of Europe (exclusive the former USSR), with and introduction for non-systematists and comments on nomenclature and conservation. Biologia, Bratislava, 52 (Suppl.5): 1-271.

Krebs Ch.J. 1985. — Ecology. Harper \& Row, Publisher; New York. $800 \mathrm{p}$.

Krno I., Sporka F., Matis D., Tirjaková E., Halgos J., Kosel V., Bulánková E. \& Illésová D. 1999. — Development of zoobenthos in the Slovak Danube inundation area after the Gabcíkovo hydropower structures began operating. Pages 175-200 in Mucha I. (ed.) Gabcíkovo part of the hydroelectric power project. Environ mental impact re vi e w. Faculty of Natural Sciences, Comenius University, Bratislava and Plenipotentiary of the Slovak Republic for construction and operation of GabË́kovo-Nagymaros hydropower Scheme, Bratislava.

Lelek A. 1987. - The freshwater fishes of Europe. Vol. 9. — Threa tened fishes of Europe. AULA-Verlag, Wiesbaden, 343 p.

Lusk S. 1995. - 1. druh Thymallus thymallus (Linnaeus, 1758) (1. Species Thymallus thymallus (Linnaeus, 1758). Pages 539-554 in Barus V. \& Oliva O. (eds.) Mihulovci Petromyzontes a ryby Os teichthyes. Fauna CR a SR 28/1. ACADEMIA, Praha.(In Czech with English summary).

Lusk S. \& Holcík J. 1998. — Význam bezbariérového spojení oícního systému Moravy a Dyje na území Ceské republiky s Dunajem (The importance of an unhindered connection of the Morava and Dyje river system in the territory of the Czech Republic with the Danube). Pages : 69-83 in Lusk S. \& Halacka K. (eds.) Biodiver zita ichtyofauny Ceské republiky II. Ústav biologie obratlovcu AV CR, Brno. (In Czech with English summary).

Lusk, S., \& Penáz, M. (eds.), 2000. - Loaches of the genus Cobitis and related genera. Folia Zool., 49 (Suppl. 1) : 252 pp.

Lusková V., Lusk S., Holcík J. \& Halacka K. 2000. — Kapr obecný divoká forma (sazan) - minulost, soueasnost a budoucnost v Ceské republice (Wild Danube carp - its past, present and future in the Czech republic). Pages 97-106 in Lusk S. \& Halacka K. (eds.) Biodiverzita ichtyofauny Ceské republiky III. Ústav biologie obratlovcu AV CR, Brno. (In Czech with English summary).

Mahen J. 1927. — Cástecná revise ryb dunajské oblasti (Partial revision of the Danube region fishes). Sborník klubu prírodoved. $V$ Brne (za r.1926), 9 : 56-59. (in Czech).

Makovinská J. 1999. — The Danube water quality between Bratislava and Visegrád (1989-1997). Pages 143-154 in Mucha I. (ed.) Gabcíkovo part of the hydroelectric power project. Environmen tal impact review. Faculty of Natural Sciences, Comenius Univers i t y, Bratislava and Plenipotentiary of the Slovak Republic for construction and operation of Gabcíkovo-Nagymaros hydropower Scheme, Bratislava.

Manea G. 1966. - Contributii la studiul sturionilur din apele României si al reproducerii lor în legatura cu constructiile hidroenergetice pe Dunarea inferioara. I. Unele aspecte ale biologiei sturionilor (Contribution to the study on sturgeons in Rumanian waters and their reproduction in relation to the hydroenergetic construction in the Lower Danube. I. Aspects of the sturgeons biology). Buletinul Institutului de Cercetari si Proiectari Piscicole, 25 : 6286.

Marsilius A.F. 1726. - Danubius pannonico-mysicus, observationi bus geographicis, astronomicis, hydrographicis, historicis, physi cis perlustratus et in sex Tomos digestus. Tomus IV. De piscibus in aquis Danubii viventibus. Hagae Comitum, Amstelodami. 89 p., 92 fol. 
Misík V. 1957. — Technika lovu rýb zát'ahovou siet'ou na Malom Dunaji pri Kolárove (Technik der Schleppnetzfischerei auf der Kleinen Donau bei Kolárovo). Polnohospodárstvo, 4 : 135-165. (in Slovak with Russian and German summaries).

Misík V. 1965. - Výskyt a rozsrenie blatniaka (Umbra krameri Walbaum, 1792) Na Slovensku (Occurrence and distribution of the mudminnow (Umbra krameri Walbaum, 1792) in Slovakia. Biológia (Bratislava), 20 : 683-688 (in Slovak).

Mucha V. \& Dub O. 1966. — Limnológia ceskoslovenského úseku Dunaja (Limnology of the Czechoslovak stretch of the Danube Ri ver). Vydavatelstvo SAV, Bratislava, $327 \mathrm{p}$.

Nagy S. \& Bastl I. 1992. — Zoobentos a ichtyofauna kanálov éitného ostrova (Die Boden- und Fischfauna der Kanäle des Grossen Schüttinsel (éitný ostrov), Südwestslowakei) Iuxta Danubiana 10. Res Naturales : 141-148 (in Slovak with German and Hungarian summary).

Nagy S. \& Cerný J. 1992. - Ichtyofauna Malého Dunaja v minulosti a dnes (Die Ichthyofauna der Kleinen Donau in der Vergangenheit und heute). Iuxta Danubiana 10. Res Naturales : 112-140 (in Slovak with German and Hungarian summary).

Ortvay T. 1902. - Poszonyvármegye állatvillága VI. Féjezet a ge rinczek kóre a halak. K. Stampfel, Poszony, 198-213.

Pavlov D.S. 1979. - Biologicheskie osnovy upravleniya povede niem ryb votoke vody (Biological base of the fish behaviour control in the water stream). Nauka, Moskva. 319 p. (in Russian).

Pavlov D.S. 1989. - Structures assisting the migrations of non-salmonid fish in the USSR. FAO Fish. Tech. Pap., 308: 97 p.

Pavlov D.S., Savvaitova K.A., Sokolov L.I. \& Alekseev S.S. 1994. - Redkie i ischezayushchie zhivotnye. Ryby (Rare and vanishing animals. Fishes). Vysshaya shkola, Moskva, 333 p. (in Russian).

Peňáz M. 1995. — 2. druh Barbus meridionalis Risso, 1826. (2.species Barbus meridionalis Risso, 1826). Pages 141-145 in Barus V. Oliva,O. (eds.) Mihulovci Petromyzontes a ryby Osteichthyes. Fauna CR a SR 28/2. ACADEMIA, Praha. (in Czech with English summary).

Peňáz M. 1996. - Chondrostoma nasus - its reproduction strategy and possible reasons for a widely observed population decline - a review. Pages 279-285 in Kirchhofer A. \& Hefti D. (eds.) Conser vation of endangered freshwater fish in Europe. Birkhäuser Verlag, Basel-Boston-Berlin.

Penczak T. 1996. - Natural regeneration of endangered fish populations in the Pilica drainage basin after reducing human impacts. Pages 121-134 in Kirchhofer A. \& Hefti D. (eds) Conservation of endangered freshwater fish in Europe. Birkhäuser Verlag, BaselBoston-Berlin.

Petrere M. Jr. 1996. — Fisheries in large tropical reservoirs in South America. Lakes \& Reserv. : Res. Manag., 2 : 111-133.

Pokorný J., Flajshans M., Hartvich P., Kvasnicka P. \& Pruzina I. 1995. - Atlas kapru chovaných v Ceské republice (Atlas of carps bred in the Czech Republic). Victoria Publishing; Praha. 69 p.

Reichenbach-Klinke H. 1968. - Fischfauna und Fischerei in der deutschen Donau. Arch. Hydrobiol., Suppl.34 (Donauforschung 1/2) : 12-23.

Ribeiro M.C.L.B., Petrere M. Jr. \& Juras A.A. 1995. — Ecological integrity and fisheries ecology of the Araguaia-Tocantins river basin, Brasil. Regul. Rivers : Res. Mgmt, 11 : 325.350.

Roux A.L. (ed.) 1982. - Cartographie polythématique appliquée à la gestion écologique des eaux. Centre National de la Recherche Scientifique, Paris. 113 p.
Sale P. F. \& Williams D.M. 1982. - Community structure of coral reef fishes : are the patterns more than those expected by chance ? Am. Nat., 120 : 121-127.

Schiemer F., Zalewski M. \& Thorpe J.E. 1995. — Land-inland water ecotones: intermediate habitats critical for conservation and management, Hydrobiologia, $303: 259-264$.

Shannon D.E. 1948. - A mathematical theory of communication. Bell System Tech. J. 27 : 379-423, 623-656.

Stepien C.A. \& Kocher T.D. 1997. - Molecules and morphology in studies of fish evolution. Pages 1-11 in Kocher T.D. \& Stepien C.A. (eds.) Molecular systematics of fishes. Academic Press, San Diego, London, Boston, New York, Sydney, Tokyo, Toronto.

Stránai I. 1997. — Neogobius kessleri v Dunaji (Neogobius kessleri in the Danube River). Polovníctvo a rybárstvo, 49 (8) : 33. (in Slovak).

Strán̆ai I. \& Andreji J. 2001. — Býcko riecny (zatial) posledný invázny druh z cel'ade býckovitých. (The monkey goby (so far) the last invasing species from the gobiids family.). Pol'ovníctvo a rybárstvo, 53 (11): 43-45. (in Slovak)

Talbot F.H., Russel B.C. \& Anderson G.Tr.V. 1978. — Coral reef fish communities: unstable, high diversity system. Ecol. Monogr., $48: 425-440$

Tóth J. 1960. — Einige Veränderungen in der Fischfauna der ungarischen Donaustrecke in der vergangenen Dekade. Annales Univ.Scient.Budapest, sect. Biologica, 3 : 401-414.

Vranovský M. 1995. - The plankton copepod taxocenoses of the Danube inland delta two years after the Gabcíkovo hydropower plant was put into operation. Pages 251-256 in Mucha I. (ed.) Gabcíkovo part of the hydroelectric power project. Environmen tal impact review. Faculty of Natural Sciences, Comenius univers i t y, Bratislava and Plenipotentiary of the Slovak Republic for construction and operation of Gabcíkovo-Nagymaros hydropower Scheme, Bratislava.

Vranovský M. 1997. — Impact of the Gabcíkovo hydropower plant operation on planktonic copepods assamblages in the river Danube and its floodplain downstream of Bratislava. Hydrobiologia, 347 : 41-49.

Vranovský M. \& Illyová M. 1999. — Zooplankton in the Danube and its left side arm system. Pages 167-174 in Mucha I. (ed.) Gabcikovo part of the hydroelectric power project. Environmen tal impact review. Faculty of Natural Sciences, Comenius univer$\mathrm{s}$ i t y, Bratislava and Plenipotentiary of the Slovak Republic for construction and operation of Gabcíkovo-Nagymaros hydropower Scheme, Bratislava.

Welcomme R.L. 1985. — River fisheries. FAO Fish. Tech. Pap., 262: $330 \mathrm{p}$.

Wiesner C., Spolwind R., Waidbacher H., Guttmann S. \& Doblinger A. (2000). - Erstnachweis der Schwarzmundgrundel Neogobius melanostomus (Pallas, 1814) in Österreich. Österreichs Fischerei $53: 330-331$

Zweimüller I., Moidl S. \& Nimmervohl H. 1996. — A new species for the Austrian Danube - Neogobius kessleri. Acta Universitatis Carolinae - Biologica, 40 : 213-218.

Zweimüller I., Guttmann S., Singer G., Schober E.M. \& Weissenbacher A. 2000. - Eine neue Fischart für Österreich - Neogobius syr man (Nordmann, 1840). Österreichs Fischerei, 53 : 186-189.

Žitnán R. 1972. — Doterajsie poznatky o ichtyofaune Dunaja pod Komárnom (Present knowledge on the fishfauna of the Danube downstream of Komárno). p.76-9 in Penáz M. \& Prokes M. (eds.) Sborník referátu z ichtyologické konference. Brno, 16.-17.3.1972. Ústav pro výzkum obratlovcu CSAV, Brno (in Slovak). 